\title{
Analyzing the effects of Energy Action Plans on electricity consumption in Covenant of Mayors signatory municipalities in Andalusia
}

María del P. Pablo-Romero ${ }^{a}$, Rafael Pozo-Barajas ${ }^{\mathrm{b}}$, and Antonio Sánchez-Braza ${ }^{\mathrm{c}}$

\section{a. Corresponding author}

Department of Economic Analysis and Political Economy

Faculty of Economics and Business Sciences, University of Seville

Ramon y Cajal 1, 41018 Seville, Spain

Universidad Autónoma de Chile, Chile

Tel.: +34 954557 611. Fax: +34 954557629

mpablorom@us.es

b. Department of Financial Economy and Operations Management Faculty of Economics and Business Sciences, University of Seville Ramon y Cajal 1 41018 Seville, Spain

Tel.: +34 954556 463. Fax: +34 954557570

pozo@us.es

c. Department of Economic Analysis and Political Economy

Faculty of Economics and Business Sciences, University of Seville

Ramon y Cajal 1

41018 Seville, Spain

Tel.: +34 954557 529. Fax: +34 954557629

asb@us.es 


\title{
Analyzing the effects of Energy Action Plans on electricity consumption in Covenant of Mayors signatory municipalities in
}

\begin{abstract}
Andalusia
ABSTRACT

The Covenant of Mayors $(\mathrm{CM})$ is an initiative by which towns, cities and regions voluntarily commit to reduce their $\mathrm{CO}_{2}$ emissions beyond the European Union climate targets, through policies promoting energy saving and renewable energy. The aim of this paper is to analyze whether joining the $\mathrm{CM}$ is reducing municipalities' electricity consumption and therefore their emissions. This analysis is made for municipalities in Andalusia, the region of Spain with more signatories. For this purpose, the evolution of total, household and public administration electricity consumption from 2001 to 2012 is analyzed by using panel data econometric techniques. Obtained results show that the $\mathrm{CM}$ is having a positive effect on the electricity consumption reductions, since the municipalities have greater rates of reduction of electricity consumption after signing the CM. Therefore, it may be considered that it may be appropriate to promote policies that incentivize the municipalities to join the CM and to develop their action plans, as this can reduce their electrical consumption.
\end{abstract}

KEYWORDS: Covenant of Mayors; electricity consumption; Energy Action Plans, panel data.

\section{Introduction}

The EU energy and climate package has set goals to reduce greenhouse gas (GHG) emissions by $20 \%$ by 2020 . To meet these goals, energy efficiency measures and increased renewable energy production and consumption should be implemented at all territorial levels, with local emphasis (Directive 2009/28/EC) (European Parliament and the Council, 2009). In this regard, some authors, such as Di Leo et al. (2015), point out that it is necessary to promote sustainable energy systems at the local scale for translating the EU's energy policies into concrete actions. The role of local authorities in tackling climate change can be traced through the emerging local sustainable energy and climate action plans which commit to voluntary emissions reduction targets (Bulkeley and Kern, 2006; Neves and Leal, 2010). 
On the one hand, it is considered that the use of local plans can have advantages for achieving the objectives of reducing emissions through more efficient use of energy and renewable energies. Thus, as van der Schoor and Scholtens (2015) affirm, some changes are being seen in the way in which energy is consumed and produced, which to a greater extent are associated with the local scale. Technological innovations are allowing the generation of renewable energies at the small scale, in such a way that the consumers are becoming "prosumers", generating energy with their CHP (combined heat and power), solar panel or windmill installations. Similarly, the number of profitable energy-cooperatives or similar organizations, which distribute energy to their own community in some European countries, is noticeably growing (Walker et al., 2010). The growing interest in the role of local organizations in the development of sustainable energies is demonstrated by the growing number of studies that investigate local community energy initiatives through case studies Among these can be highlighted the studies by Brito et al. (2014), Mårtensson and Westerberg (2007), and Viardot (2013).

On the other hand, it is considered that the local plans might resolve some of the problems associated with the growing energy consumption linked to the increasing urbanization of society. Consequently, an increasing number of studies analyze how urbanization is affecting energy consumption. The study by Li and Lin (2015) review nearly 40 studies analyzing the impact of urbanization on energy consumption. Likewise, several studies analyze the channels through which urbanization may increase energy consumption. In these studies it is possible to identify three main associated sectors: residential households, transportation and the building material industry (Jones, 1991; Leach, 1992; Poumanyvong, 2012). However, there are also significant mechanisms reducing energy demand in urban buildings and urban transportation systems (Ma, 2015). Thus, for example, Zhang et al. (2016) considered that energy efficiency plays an important role in decreasing urban residential energy consumption. Thus, energy consumption varies according to local patterns, and the measures implemented to reduce energy consumption should be associated with those characteristics. It is for this reason that a growing number of papers are focused on the identification of the most suitable scales for energy planning. Among them may be cited Bhatt et al. (2010), Hallegatte et al. (2011), Prasad et al. (2014), and Sovacool (2011). In these papers, as stated in Pasimeni et al. (2014), there is a wide and growing recognition of the importance of the local scale for energy planning. 
The growing recognition of the contribution of local areas to energy and environmental policies has led to important initiatives for the reallocation of planning actions. Some of the most recent initiatives are the "C40 Cities" network, and "Covenant of Mayors" (CM). At the European level, in January 2008, the European Commission initiated the $\mathrm{CM}$, which is a voluntary agreement between local governments by which towns, cities and regions voluntarily commit to reduce their $\mathrm{CO}_{2}$ emissions beyond the $20 \%$ target, through policies promoting energy saving and renewable energy. To this end, signatories undertake to develop specific action plans, by means of which they have the opportunity to have an impact on the climate change initiative (Radulovic et al., 2011). Therefore, the launch of the CM can be seen as an interesting evolution in the way European policies are implemented, due to municipalities taking a more active role in committing to the European energy and climate targets (Labaeye and Sauer, 2013; Pablo-Romero et al., 2015b). Dawson et al. (2014) state that CM seemed conducive to successful mitigation planning, although Reckien et al. (2014) consider it necessary to gain more knowledge about potential drivers of, and barriers to, the development of these plans in Europe.

However, the development of local action plans that promote energy efficiency or the use of renewable energies is not always an easy task. Thus, some studies have focused on the difficulties of financial support faced by municipalities in developing their action plans (Christoforidis et al, 2013). Other studies point out technical difficulties. Marinakis et al. (2012) point out that the lack of technical capacity and limited resources are important barriers, in some areas, to undertaking the requirements of the CM action plans (called Sustainable Energy Action Plan - SEAP) and promoting renewable energy or energy efficiency measures, with these being especially relevant for some rural areas Marinakis et al. (2015b). These difficulties have spawned a growing number of studies which develop methodologies that provide local administrations with analytical support tools to guide decisions in energy and climate planning. In this regard, the studies by Bjelic and Ciric (2014), Kyriakarakos et al. (2014), and Mirakyan and De Guio (2013) can be highlighted, among others. In addition, some studies have focused on the technical aspects of the preparation of the action plans of some signatory municipalities and their results through case studies. Thus, for example, Lombardi et al. (2014), report on the methodology used in the 
production of the action plans and the achieved results in 36 municipalities of the province of Foggia.

Despite the incipient interest in the study of the local authorities planning to promote energy efficiency and the use of renewable energies, little has been said about the impact of these plans. Thus, in the framework of the action plans made by the CM signatories, there are several reports related to energy savings or emissions reduction targets, such as, for example, those by Cerutti et al. (2013), Kona et al. (2015), and Melica et al. (2014) referring to the CM initiative. The study by Pablo-Romero et al., (2015a) analyses the estimated emissions reductions by the signatory municipalities and the reasons for the differences observed between them. Nevertheless, to the extent of our knowledge, there are no studies on whether joining the CM and making action plans is having a positive impact on reducing emissions through energy saving or promoting renewable energy. The fact that the first municipalities only joined the CM from July 2008 should be taken into account, so this may be the reason that assessments of the results have still not been carried out, and that only descriptive studies on action plans have been developed by the signatory municipalities.

The aim of this paper is to analyze whether joining the $\mathrm{CM}$ and developing the corresponding SEAP is reducing municipalities' electricity consumption and therefore their emissions. This analysis is made for municipalities in Andalusia. It is noteworthy that Spain is currently one of the countries with the largest number of signatory municipalities, second to Italy. Andalusia, in turn, is the region of Spain with more signatories. Additionally, the availability of local data allows this analysis for these municipalities. With this objective, the evolution of electricity consumption in Andalusian municipalities from 2001 to 2012 is analyzed, and it is investigated whether this consumption has been influenced in recent years by joining the $\mathrm{CM}$ and developing action plans.

For this purpose, the evolution of total, household and public administration electricity consumption are related to the income of municipalities, and analyzed by using panel data econometric techniques. Thus, a regression function is estimated with panel data in which the electricity consumption of each municipality depends on their income and a number of control variables, according to Grossman and Krueger (1991), He and Richard (2010), Luzzati and Orsini (2009), Menegaki (2014), and Selden and Song (1994), including being a CM signatory as a categorical variable, which takes the value 
1 if the municipality is a $\mathrm{CM}$ signatory in the year considered. The regressions are estimated taking into account the endogeneity problems between electricity consumption and income detected in numerous, previous studies and recently reviewed in Caraiani et al. (2015). Additionally, possible multicollinearity problems detected in previous studies, as in Narayan and Narayan (2010), have been considered.

Thus, this paper is organized as follows: Section 2 provides a literature review. Section 3 offers a descriptive analysis of data. Section 4 analyzes the methodology used to carry out the empirical analysis. Results and discussions are contained in Section 5. Finally, Section 6 concludes.

\section{Literature review}

The study by Bulkeley et al. (2012), which analyzes the role of cities in responding to climate change, since the agreement of the United Nations Framework Convention on Climate Change two decades ago, finds a growth of municipal responses to climate change, reflected by the rising number of adoptions of local climate strategies. The growth of cities' climate strategies has brought about an increase in the number of comparative studies of cities in recent years, which analyze cities' or municipalities' adaptation and mitigation plans. Among them, the study by Reckien et al. (2014), analyzing these plans from 200 urban areas in 11 European countries, may be cited. Likewise, the impact of national strategies on 200 European cities' strategies has also been recently analyzed, finding that there is no archetypical way of planning for climate change (Heidrich et al., 2016). Nevertheless, the authors show that many European cities are proactive on climate change. These cities seek national guidance, but if this is not available they align themselves to international networks such as the ICLEI (International Council for Local Environmental Initiatives), C40 cities and the CM. In fact, some authors, such as Fünfgeld (2015) and Hakelberg (2014), highlight that the growth of cities' climate strategies has been promoted by transnational municipal networks, which are considered to have a positive impact which exceeds that of most other explanatory factors, cited in the literature. This lack of clear guidance has contributed to the current sparseness of cities considering adaptation issues in their climate plans (Olazabal et al., 2014). In this regard, Martos et al. (2016) offer an analysis of the aspects involved in designing these sustainable cities. 
The CM is a bottom-up movement launched by the European Commission that succeeded in mobilizing local authorities to developing sustainable energy policies. Cities or municipalities sign an agreement by which they commit to reduce emissions by at least $20 \%$ by 2020 , through energy efficiency and renewable energy actions. Signatories commit to implement a SEAP which defines the measures set up to achieve the targets.

To facilitate the preparation of sustainable action plans from the cities, in particular SEAPs in the CM, signatory cities have been developing a set of toolkits, which have been implemented in the development of SEAPs of some municipalities, and which have been analyzed. Table 1 shows the studies analyzing these toolkits created to facilitate the production of SEAPs in some signatory municipalities.

\section{[Table 1]}

Galante and Pasetti (2012) developed a toolkit for estimating the potential energy savings of retrofitting residential building stocks, which were applied to five CM signatory municipalities in the province of Milan. Dall'O et al. (2013) also developed a toolkit, based on the ELECTRE III method that integrates multi-criteria analysis to support local public administrators in programming SEAPs with a more targeted approach to sustainability. This methodology was applied to a municipality in the Lombardy region of Italy. Likewise, Bjelic and Ciric (2014) presented the results of the application of the simulation tool HOMER, for the configuration plan of the municipal microgrids for Serbia, in order to prepare their SEAPs. Likewise, Marinakis et al (2015a), presented a tool for the production of rural communities' SEAPs, consisting of an interactive supportive framework made into a web application. Also, Kyriakarakos et al. (2014) developed a tool implemented on a web platform to simplify decision support systems consisting of a fuzzy cognitive maps decision toolkit for renewable energy sources planning, which was tested by application in real investments in the Island of Crete. The rapid development of these techniques applied in the preparation of SEAPs in $\mathrm{CM}$ signatories, and in the local or regional climate plans in other cities, has generated a proliferation of available tools, some of them through the web, which can be used by local policymakers. Mirakyan and De Guio (2013) review the methods and the tools that are used for these diverse planning tasks. 
Additionally, the experience of some municipalities after joining the $\mathrm{CM}$, or in developing their SEAPs, is interesting for other municipalities that intend to join it or develop their own action plans. In this regard, some studies have explained the experiences and difficulties involved and the manner of addressing the development of these plans in municipalities of specific or particular geographical areas. Table 2 shows these studies.

\section{[Table 2]}

Among these studies may be pointed out that by Christoforidis et al. (2013) concerning the $\mathrm{CM}$ initiative in Greece, focusing on the identified barriers preventing the realization of the initiative's full potential. Following this line, Pablo-Romero et al. (2015b) analyzed which factors influence the decision of Spanish local authorities to join the ever-growing movement. Meanwhile, Lombardi et al. (2014) reported on the methodology used for the production of the SEAPs of a total of 36 municipalities of the province of Foggia which signed the CM agreement in 2010. Famoso et al. (2015) analyzed the CM initiative in Sicily. Marinakis et al. (2015b) analyzed the local communities' needs in order to identify the parameters that should be taken into consideration during the development of the SEAPs in rural communities from Austria, Croatia, Greece and Portugal. Also referring to rural communities, Doukas et al. (2012) assessed communities' energy sustainability using the Principal Component Analysis on mountainous and agricultural communities and islands. Oliver-Solà et al. (2013) focused on analyzing the energy consumption and emissions of the municipal service facilities in Barcelona in 2005, with the goal of compiling the actions that the municipalities should undertake in order to fulfill their SEAP pledges. Magni and Maragno (2014) described the SEAPs in Italy and defined a study for a Local Action Plan for Climate in the Province of Rovigo. Damsø et al. (2016) examined the climate action plans of local governments in Denmark. Likewise, Heidrich et al. (2013) analyzed the adaptation and mitigation action documents across 30 urban areas of the UK (although not all were signatories of the CM). From a wider perspective, Rivas et al. (2015) carried out an analysis of the SEAPs of 25 municipalities from different EU Member States, extracting their common and most important characteristics. These authors highlighted the considerable importance given to the involvement of civil society in the plan. 
Following this perspective, some studies have evaluated the evolution of CM signatories and the main questions related to the SEAP objectives (Table 3). Amorim (2014) explored the content of various SEAPs, providing an overview of existing methodologies in order to identify good practices and guidelines for increasing participant municipalities. Cerutti et al. (2014) presented the main figures of CM from a five year perspective, Melica et al. (2014) provided an assessment and evaluation, and Kona et al. (2015) again provide an assessment of the CM initiative, but 6 years after it was initiated. Additionally, Iancu et al. (2015) presented a collection of emission inventories at municipal level, computed by the cities and towns that participate in the $\mathrm{CM}$, showing the heterogeneity of final energy consumption and greenhouse gas emissions of these cities. Following this study, Pablo-Romero et al. (2015a) analyzed the local $\mathrm{CO}_{2}$ emissions reduction targets in SEAPs and related them to some basic indicators.

\section{[Table 3]}

Nevertheless, despite the incipient diffusion of these analyses, to our knowledge, there are no studies examining whether municipalities belonging to these transnational networks, in particular to the CM, (and the subsequent implementation of SEAPs) are reaching the main objective of reducing emissions through energy savings and renewable energy use increases. This paper aims to contribute to enlarging this literature by analyzing if the participation in the $\mathrm{CM}$ and the implementation of SEAPs is contributing to the reduction of energy consumption. In this regard, this paper may help to answer the questions asked by Fünfgeld (2015): does network participation result in more effective, additional, and 'better' climate change responses, or is some of it just rhetoric? To do this, data was used from Andalusia, one of the European regions with the highest participation of municipalities in the $\mathrm{CM}$ for which sufficient information is available.

\section{Data and descriptive analysis}

\subsection{Signatory municipalities}

Since the CM began in 2008, many municipalities and local authorities have signed accession agreements and developed SEAPs. These agreements and SEAPs are 
presented in the organization's web (Covenant of Mayors, 2016) and are under constant review. In January 2016, there were 6,033 signatories. Of these, 5,970 were European, 52 Asian, 9 African, one American (Chile) and one from Oceania (New Zealand). 5,783 European signatories are from the European Union, with 5,406 being from the Eurozone.

\section{[Figure 1]}

Figure 1 shows the proportion of the population involved in the CMs of each European country. The pie chart of each country also shows the total population size (area of the pie chart), and the percentage of people involved each year. The most committed countries, in proportion to their population, are Italy (65.01\%), Greece $(62.03 \%)$, Belgium (61.81\%), Spain (57.91\%), Portugal (56.67\%), Denmark (56.20\%) and Latvia $(55.12 \%)$. Depending on the total number of people involved, the main countries are Italy $(39,874,275)$, Spain $(26,871,701)$, the United Kingdom $(17,422,543)$, Germany $(17,419,470)$ and France $(15,190,417)$.

Italy and Spain stand out both for the proportion of people involved and for the number of signatory municipalities. If the date of involvement of these inhabitants (sections 2008 and 2009 of each pie chart) is also considered, Figure 1 shows that Spain is the country with a higher initial involvement.

In Spain, as shown in Figure 2, the regions which have a higher percentage of signatory municipalities are Andalucía (69.13\%), Murcia (62.22\%) and Catalonia (52.69\%), with the provinces of Alicante and Zaragoza also highlighted. Andalusia is highlighted for the population affected by CM membership $(6,952,130)$, being followed by Catalonia $(6,648,352)$, Madrid $(4,021,104)$ and Valencia $(3,022,185)$.

\section{[Figure 2]}

Therefore, Andalusia is the Spanish region with more signatories and more population affected by CM. Likewise, it may also be noted that most Andalusian municipalities signed the CM in the first years (brown color in Figure 2). Therefore, it may be stated that Andalusia in one of the regions most involved with the CM in the world. 


\subsection{Signatory municipalities in Andalusia}

According to data provided by the organization of the CM (Covenant of Mayors, 2016), by January 2016, a total of 6,033 municipalities, representing 211,624,452 inhabitants, mainly European, had signed it since its inception in 2008. Of these, 1,439 are Spanish municipalities, with Andalusia being the Spanish region with most signatory municipalities (533). The data used in this paper refer to CM signatories in Andalusia up to December 2012, due to data availability limitations for all sources used in the study.

The organization of the $\mathrm{CM}$ divides the municipalities into five groups according to their size: XS (very small, $<10,000$ inhabitants), S (small, 10,000-50,000 inhabitants), M (medium, 50,000-250,000 inhabitants), L (large, 250,000-500,000 inhabitants) and $\mathrm{XL}$ (very large, $>500,000$ inhabitants). Figure 1 shows the $\mathrm{CM}$ signatory municipalities in Andalusia in green and the non-signatories in orange. The smaller municipalities are shown in lighter shades, while the larger ones are in darker shades. It should be highlighted that $68.5 \%$ of the municipalities in Andalusia had signed the CM by December 2012, most being very small and small municipalities. Nevertheless, all large and very large municipalities are signatories, while only $75 \%$ of medium, $85 \%$ of small and $65.7 \%$ of very small municipalities are. Additionally, Figure 1 shows that nonsignatory municipalities are concentrated in certain geographical areas, mainly in Cordoba and Granada. As stated in the Joint Research Centre report (Cerutti et al., 2013), some provinces in the Spanish public administrations have signed up to the initiative as Covenant Territorial Coordinators which provide strategic guidance, financial and technical support to those municipalities signing up to the CM but which lack the necessary skills and/or resources to fulfill their requirements. In Andalusia, Seville, Cadiz and Huelva deputations have signed as Covenant Territorial Coordinators, and therefore promote the signing of municipalities in their territories.

\section{[Figure 3]}

\subsection{Electricity consumption}

Electricity consumption data come from the Multi-territorial Information System of Andalusia (SIMA) database (SIMA, 2015). SIMA offers data for the electricity 
consumption in the Andalusian municipalities from 2000 to 2012. The information provided relates only to the electricity distributed by the Endesa Electrical Distribution Company. Nevertheless, this company provided $94 \%$ of the electricity distributed in the region. The rest of the electricity is distributed by a few companies which are localized in some municipalities. These municipalities have been excluded from the analysis. Therefore, nearly $100 \%$ of the electricity consumption is registered in the data used. The data come from billings to subscribers and are expressed in megawatt hours/year.

The SIMA database offers information about total electricity consumption (from 2001 to 2012) and sectoral consumption in each municipality: residential, industrial, agricultural, and public administration. In this paper, total electricity consumption has been considered. Additionally, the residential and public administration sectors have also been analyzed, as these are the main sectors around which the actions of all the signatory administrations are designed, such as: the modernization of the administrations, clean mobility, energy requalification of public and private buildings and raising citizen awareness about responsible energy use. Additionally, Kona et al. (2015) point out that the highest values of energy consumption are reached in the residential sector.

The CM established measures to reduce the energy consumption including fuel energy. Nevertheless, as stated in Pablo-Romero et al. (2015a), when municipalities relatively increase the number of actions in the transport sector (fuel energy) versus other types of measures, the predicted reductions in emissions by municipalities are smaller. It is also important to highlight that the highest share of energy savings $(52 \%$ of the total energy savings) is estimated in Kona et al. (2015) to take place in the building sector by the introduction of efficiency requirements in building codes, more efficient space and water heaters. Therefore, reduction in the electrical consumption is the main measure to reduce energy consumption in $\mathrm{CM}$ signatory municipalities, especially in southern countries.

It is worth noting that Andalusia stands out for its higher electricity consumption, resulting from higher appliance equipment and higher power consumption associated with refrigeration and heating (IDAE, 2011). In that sense, as stated in the Andalusia Energy Agency report (AAE, 2015), Andalusia stands out for the higher electricity consumption percentage respect to the European Unión. Thus, while the electricity consumption respect to the final energy consumption is around $18.9 \%$ in the EU, it is 
almost $24 \%$ in Andalusia. Additionally, this report indicates that the electricity production is mainly generated by fossil fuels currently; being 38\% generated by renewable energies, especially wind energy. Nevertheless, Andalusia has to import electricity energy from others regions. In that sense, the electric generation-self rate is $83 \%$, being this rate decreasing since 2011.

The electrical consumption variable has been converted into logarithm terms and expressed in per capita terms. Population data also come from the SIMA database.

Figure 4 shows the average electrical consumption per capita in the Andalusian municipalities by size, for signatory and non-signatory municipalities. Data refer to 2008 and 2012, as the European Commission launched the CM in 2008, after the adoption of the EU Climate and Energy Package. No municipalities joined the CM in 2008 in Andalusia. Figure 4 show that the electricity consumption increases with the size of the municipality, except for larger municipalities, which had the lowest electricity per capita consumption in signatory municipalities in 2012. This result is in line with Pablo-Romero et al. (2015a). The authors find that the greater consumption in all CM signatories is seen in municipalities of between 100 and 500 thousand inhabitants, whereas the least is observed in the largest cities. Likewise, Figure 4 shows that on average, municipalities of all sizes have reduced the electricity consumption. No mayor differences are observed between signatories and non-signatories, as in general all municipalities decrease their electrical consumption in per capita terms, which may influenced by the income decreased related to economic crisis. In that sense, recent studies have documented an S-shaped relationship between expenditure level and ownership of appliances and other energy-using assets (Gertler et al, 2016; McNeil and Letschert, 2010). Nevertheless, the signatories, of each size, have higher electricity consumption in both years. Finally, it is also worth highlighting that the smallest municipalities are those that have least reduced their electricity consumption. Melica et al. (2014) find that the energy savings that can be achieved in 2020 by the smallest municipalities are low considering the administrative and technical support needed.

\section{[Figure 4]}

Figure 5 shows the average electrical consumption per capita in the Andalusian municipalities by size, for signatory and non-signatory municipalities, for both residential (Figure 5A) and public administration (Figure 5B) electricity consumption. 


\section{[Figure 5]}

Figure 5 shows two main differences with respect to Figure 4. The first difference is related to residential electricity consumption. Figure 5A shows that the lowest electricity per capita consumption is observed in the smallest municipalities, for both signatories and non- signatories and in 2008 and 2012. These results are in line with Pita and Orozco (2012), who find that large cities in Andalusia have quite moderate consumption per inhabitant, although without taking the lowest range, which usually corresponds to small municipalities located in hilly areas. According to the authors, the lower electricity consumption per inhabitant may be related to the presence of an aging and low-consuming population. Likewise, Figure 5A shows that residential electricity consumption increased in the smallest signatory municipalities, which may be related to the reduction of population in these areas.

Figure 5B, shows a very similar picture of total electricity consumption for public administration. Nevertheless, it is worth pointing out that the smallest signatories have a small electricity consumption reduction, such that their average electricity consumption is the highest of the sample in 2012.

\subsection{Income data}

Two main sources are taken into account in this paper related to income, as there are no macroeconomic municipality income data available. First, the net results of the declaration of personal income taxes have been considered as a proxy for households' income. Data come from SIMA (2015) and are available from 2000 to 2012. The data, expressed in current euros, have been converted into 2005 constant euros. Second, current revenues of municipality liquidated government budget have been used as a proxy for municipality administration income. These data also come from SIMA (2015) and are available from 2002 to 2012, they have also been converted into 2005 constant euros.

Figure 6 shows the average electrical consumption per income in the Andalusian municipalities by size, for signatory and non-signatory municipalities, for both residential (Figure 6A) and public administration (Figure 6B) electricity consumption. 
Figure 6A shows household electrical consumption per household income, while Figure 6B shows public administration electrical consumption per public administration income.

\section{[Figure 6]}

Figure 6 shows that electricity consumption per income has growth in all cases, for residential consumption and public administration, for every municipality size and for signatories and non-signatories. The decrease in income in the municipalities, due to the economic crisis, has not led to a proportional reduction in electricity consumption, and therefore relative values have increased.

Some differences are observed between Figure 6A and 6B. On the one hand, Figure 6A shows that residential electricity consumption per income unit is higher in smaller municipalities, with slightly lower values in signatories, except for size XS and 2012. On the other hand, Figure $6 \mathrm{~B}$ shows that public administration electricity consumption per income unit is higher in signatory municipalities for each year and size. It should also be highlighted that the smallest size signatory municipalities had the biggest increase in electricity consumption.

The previous descriptive analysis of electricity consumption in Andalusian municipalities shows that in average municipalities have decrease their electricity consumption per capita, while have increased it in per income terms. Therefore crisis may have influenced their consumptions. Nevertheless, some others factors have influenced in their electricity consumption, as for example differences are observed in terms of municipality's size.

Apparently no major differences between signatories and non-signatories of CM municipalities are observed. In this sense, the graphic analysis does not allow to show whether the reduction of electricity consumption in per capita terms are higher in some municipalities than in other. In this regard, it should be noted that all municipalities seem to be strongly influenced by the economic crisis and decreasing income, which may be masking potential reductions due to the signing of the CM.

In this sense, it should be noted that the data shown are expressed in average terms, so that a more detailed analysis of the data is necessary to capture whether these differences between signatories and non-signatories municipalities exists or not. It 
may therefore be appropriate to perform an econometric analysis of the data allowing studying the electricity consumption per capita considering signatories and non-signatories municipalities, taking also into account the effect of income and other variables such as the size of the municipalities.

\section{Methodology}

To analyze whether the evolution of electricity consumption in the Andalusian municipalities has been influenced by joining the $\mathrm{CM}$, the relationships between electricity consumption in households and public administrations and the income of municipalities are analyzed, including a set of control variables. Among these control variables, the membership, or not, of the $\mathrm{CM}$ has been included to analyze its influence on electricity consumption.

The relationship between income and energy use has been explained by many authors through the Energy-Environmental Kuznets Curve (EKC). The EKC curve arises under the hypothesis that there is an increasing relationship between income growth and environmental pressure until some turning point of income per capita, from which point additional increases in income lead to enhanced environmental quality ([7] and PabloRomero and De Jesus (2016). The later use of energy consumption as an indicator of the environmental pressure has propagated the term "Energy-Environmental Kuznets Curve". Among the studies using energy indicators in the EKC it may be highlighted among others the studies by Luzzati and Orsini (2009), Pablo-Romero and De Jesus (2016), Saboori and Sulaiman (2013), Suri and Chapman (1998) and Zilio and Recalde (2011).

The relationship between income and electricity consumption has been also analyzed in the last decades by numerous studies, as for example Ferguson et al. (2000), Narayan and Prasad (2008), and Karanfil and Li (2015), among others, showing the overall findings that there is a strong relationship between both variables. Recently, some authors have used the EKC methodology to estimate the relationships between electricity consumption and income, especially to show the potentially severe repercussions of excessive electricity consumption, as in Yoo and Lee (2010) and Yin et al. (2016). 
The standard cubic EKC specification used in this previous literature is expressed as follows:

$$
E_{i t}=A_{\mathrm{it}}+\beta_{1} Y_{i t}+\beta_{2} Y_{i t}^{2}+\beta_{3} Y_{i t}^{3}+Z_{i t}+e_{i t}
$$

where $E$ is an energy consumption indicator in per capita terms expressed in logarithms, $Y$ is the income per capita expressed also in logarithms, $A$ is the sum of the time effect and individual effect and $Z$ is a set of control variables that impact energy consumption which is included to control for heterogeneity among individuals to avoid incorrect estimates (Piaggio and Padilla, 2012). Finally, $e$ is a random error term.

Several econometric problems have been observed in previous studies when estimating the EKC. Narayan and Narayan (2010) have perceived multicollinearity problems among the explanatory variables. Values of variance inflation factors (VIFs) have been analyzed in order quantify the severity of multicollinearity among explanatory variables in a regression analysis. In general, it is recommended that for each explanatory variable the value of VIF should not exceed the value of 10 since, being equivalent to a 0.1 for the tolerance indicator $(1 / \mathrm{VIF})$. Nevertheless, more stringent criteria recommend a maximum VIF of 5, equivalent to a value of 0.2 for the tolerance indicator (PabloRomero et al., 2015b; Sánchez-Braza and Pablo-Romero, 2014). In order to mitigate these problems the data were converted to deviations from the geometric mean of the sample as in Pablo-Romero and Sanchez-Braza (2015).

Additionally, other authors have pointed out possible spurious estimates in some previous studies when testing the EKC (Stern, 2014). In order to avoid spurious estimates data are also converted in first differences, as for example in De la Fuente (2008). Italics with line have been used to indicate these deviations and $\Delta$ indicates first differences. Therefore, the model general specification is expressed as follows

$$
\overline{\Delta E}_{i t}=\delta_{\mathrm{t}}+\beta_{1} \overline{\Delta Y}_{i t}+\beta_{2} \overline{\Delta Y}_{i t}^{2}+\beta_{3} \overline{\Delta Y}_{i t}^{3}+Z_{i t}+e_{i t}
$$

where $E$ is a measure of electricity consumption per capita (in logs), being alternatively total, residential and public administration electricity consumption. $Y$ is the income per capita (in logs). $Y$ is a measure of personal income when estimating for total and residential electricity consumption while $Y$ is a measure of administration budget revenues for public administrations. $\delta$ is a common temporal fixed effect for all the 
municipalities, $Z$ is a set of control variables and $i$ and $t$ denote Andalusian municipalities and years, respectively. Finally, $e$ is a random error term.

From [2], the effect of CM could be tested when including this variable as a control one. With this aim, the set of control variable $Z$ may be expressed as:

$$
Z_{i t}=\beta_{4} C M_{i t}+\beta_{5} \overline{\Delta D}_{i t}+\beta_{6} S E_{i}
$$

where $C M$ is a dummy variable which takes the value 1 if the municipality joined the $\mathrm{CM}$ in that year, or 0 if it did not.

Additionally, the $D$ and $S E$ variables have been included to control for different structures of each municipality. $D$ indicates the population density and $S E$ represent the size effect indicating the size of the municipality. In this regard, previous studies have considered that the predicted emissions reduction by $\mathrm{CM}$ signatories is related to energy use per capita, and that this energy consumption depends on the size of the municipality (Pablo-Romero et al., 2015a). Likewise, previous studies have considered that population density affects environmental degradation (Kaufmann et al., 1998).

Thus, it is possible to rewrite [2] as follows:

$$
\overline{\Delta E}_{i t}=\delta_{\mathrm{t}}+\beta_{1} \overline{\Delta Y}_{i t}+\beta_{2} \overline{\Delta Y}_{i t}^{2}+\beta_{3} \overline{\Delta Y}_{i t}^{3}+\beta_{4} C M_{i t}+\beta_{5} \overline{\Delta D}_{i t}+\beta_{6} S E_{i}+e_{i t}
$$

Equation [4] is estimated for total, residential and public administration electricity consumption. For all cases, equation [4] is estimated taking into account, or not, the cubic term of the variable $Y$, as previous estimates have sometimes used quadratic functions (Grossman and Krueger, 1991; Selden and Song, 1994) and at other times cubic functions allowing a greater range and modeling flexibility (Ahmed and Long, 2012; He and Richard, 2010; Luzzati and Orsini, 2009).

As all municipalities are included in the estimates (signatories and non-signatories), the estimated coefficient related to the adherence to the $\mathrm{CM}$ ( $\beta_{4}$ coefficients) informs about the effect of $\mathrm{CM}$ membership on electricity consumption. If this coefficient is significantly negative, then the Sustainable Energy Action Plans developed by signatory municipalities are having positive results, and these municipalities are reducing electricity consumption in their territories due to the energy measures implemented. If this coefficient is significantly positive, then the adherence to the $\mathrm{CM}$ is having negative results. If this coefficient is non significative, then the adherence to the $\mathrm{CM}$ is not 
having any effects, so being a signatory or non-signatory municipality has no effect in electricity consumption.

Additionally, the estimated $\beta_{1}, \beta_{2}$, and $\beta_{3}$ coefficients show the relationships that exist between electricity consumption and income. If $\beta_{1}>0, \beta_{2}<0$ and $\beta_{3} \leq 0$, then an inverted $\mathrm{U}$ relationship (EKC) exists (Dinda, 2004). If $\beta 1>0$ and $\beta 2>0$ and $\beta_{3}$ is close to zero or non significative, then there is a positive relationships between electricity consumption and income. Thus, if income decreases, for example due to the economic crisis, then the electricity consumption will also decrease.

Therefore, the estimate of [4] allows assessing to what extend the economic crisis or the $\mathrm{CM}$ action plans have influenced in the electricity consumption per capita reduction observed in the descriptive analysis.

Equation [4] has been initially estimated by feasible generalized least squares (FGLS). Nevertheless, there may be endogeneity problems between electricity consumption and income, as detected in previous studies (Caraiani et al., 2015). So, in that case, the estimation of equation [4] may be considered using techniques of instrumental variables by the generalized method of moments (GMM), because the estimation of the model by FGLS is not consistent when the regressors are not exogenous.

\section{Results and discussion}

The preliminary analysis shows notable differences between electricity consumption in signatory and non-signatory municipalities, although the evolution from 2008 to 2012 seems to be quite similar between both groups. Additionally, notable differences are observed between municipalities when size is considered, and between residential and public administration electricity consumption.

To give more depth to the preliminary analysis, equation [4] has been estimated for total, residential and public administrations municipalities' electricity consumption in per capita terms. Equation [4] has been estimated for a panel data of 636 municipalities during the 2001-2012 time period for total and residential electricity consumption, and for 434 municipalities during the 2002-2012 time period for public administration. In all estimates, the panel data sample includes signatories and non-signatories of the CM. These differences between samples of data depend on availability of data. In each case, 
a wider homogeneous database has been chosen. Electricity consumption per capita is measured as $\mathrm{MWh} / \mathrm{pc}$ in logs, income is measured in thousand euros per capita in logs (personal income for total and residential and current budget revenues for public administration estimates). $\mathrm{CM}$ is a discrete variable which takes the value 1 , if the municipality signed the CM that year, and 0 otherwise. Population density is measured as $\mathrm{Km}^{2}$ per capita in logs and finally, size takes values 1-4, 1 being for XS, 2 for S, 3 for $\mathrm{M}$ and 4 for $\mathrm{L}$ and XL municipalities.

Table 4 shows the results of estimating equation [4] for total, households and public administration electricity consumption in per capita terms. The estimates are obtained using the FGLS method in the presence of autocorrelation and heteroscedasticity, according to the results of the Wooldridge test for autocorrelation (Wooldridge, 2002), the Wald test for homoscedasticity, proposed in Greene (2000), and the Pesaran test for contemporaneous correlation (Pesaran, 2004). Additionally, Table 4 also shows the estimates of the model using techniques of instrumental variables by the GMM method, as the estimation by FGLS is not going to be consistent when the regressors are not exogenous. This suggests the need for modeling the non-exogenous variable as predetermined, so that the estimate is unbiased. In order to manage this problem, parameters in equation [4] were estimated by GMM, considering that the income per capita is an endogenous variable, and taking the explanatory variables of incomes at values delayed by one and two periods as instruments. Additionally, values of VIFs have been analyzed in order quantify the severity of multicollinearity among explanatory variables. Obtained values of VIFs have been included in Table 5. In general, it is observed that for each explanatory variable the value of VIF do not exceed the value of 5 when variables were converted to deviations from the geometric mean of the sample, thus ruling out possible problems of multicollinearity. Therefore, there were not problems with the efficiency of the estimators obtained.

\section{[Tables 4 and 5]}

Table 4 show that the coefficients related to adherence to the $\mathrm{CM}$ ( $\beta_{4}$ coefficients) are negative and significant in all estimates, which reflects that the per capita electricity consumption growth rate decreased since the municipality joined the $\mathrm{CM}$, that is to say that municipalities have greater rates of reduction of electricity consumption after signing the CM. Therefore these municipalities are reducing electricity consumption in their territories due to the energy measures implemented. Thus the $\mathrm{CM}$ is having a 
positive effect on the electricity consumption reductions. In this sense, the obtained results may indicate that participation in this network $(\mathrm{CM})$ is effective and not just rhetoric, as queried in (Fünfgeld, 2015).

Therefore, if CM participation have positive effects on electricity savings, it may be considered appropriate to promote measures to incentivize municipalities to join the $\mathrm{CM}$ and develop action plans, as these plans may be a channel through which to reduce electricity consumption. Pablo-Romero et al. (2015b) state that one of the main factors that influences the municipal decision to join the $\mathrm{CM}$ is the existence of Covenant Coordinators. Likewise, Cerutti et al. (2013) and Rivas et al. (2015) find that Covenant Coordinators are playing an important role in helping municipalities to implement sustainable energy policies. Therefore, promoting Covenant Coordinators may be influential in encouraging municipalities to join the CM and developing their SEAPs.

Additionally, it is worth noting the importance of these action plans for developing renewable energies. For example, Lybæk and Kjær (2015) highlight the role of local authorities as facilitators to support biogas. Likewise, Doukas et al. (2012) consider that renewable energies are the key to achieving the targets of $\mathrm{CM}$ signatory municipalities, especially for most rural communities which have large unexploited renewable energies potential. Nevertheless, as stated in Rivas et al. (2015), only $15 \%$ of total energy reduction relies on renewable electricity production, when looking at data in terms of population, and even less when considering data by number of signatories.

The greatest coefficient value for $\mathrm{CM}$ is observed for residential electricity consumption, the estimated coefficient for total electricity consumption being the lowest. Therefore, the importance given to the involvement of civil society in the SEAPs may be pointed out, which is finally reflected in residential actions (Rivas et al., 2015). In that sense, as stated by Jadraque et al. (2011), one the guidelines proposed in the Strategy for Energy Conservation and Efficiency in Spain (IDAE, 2007) for the reduction of electricity consumption for lighting in buildings was the replacement of conventional incandescent light bulbs with energy-saving light bulbs. In this regard, one of the measures included in most of the SEAPs of signatory municipalities in Andalusia has been related to promote this light bulbs replacement. Additionally, González-Limón et al. (2013) pointed out that being a CM signatory municipality influence the decision of local government to implement tax credits up to 50\% in Real Estate Tax to promote the installation of solar electrical energy systems. In this line, Sánchez-Braza and Pablo- 
Romero (2014) find that these tax credits were an effective tool to promote these energy systems in Andalusia. The authors conclude that municipalities that established a property tax credit installed, on average, 102.245 to 122.389 square meters more, indicating that the percentage increase in squares meters installed in municipalities which adopted the tax credit promotion ranged from $70.74 \%$ to $98.38 \%$.

Along this line, Kona et al. (2015) find that $43 \%$ of total final energy consumption reported in the Baseline Emission Inventories of CM signatories is residential building final energy consumption, and most of the measures implemented to reduce energy also refer to the building sector, which finally may directly affect residential consumption. Therefore, more research may be necessary to analyze the effect of specific implemented measures, as the results may help municipalities to design more useful measures in their actions plans to reduce energy consumption and emissions. Nevertheless, general or global analyses are to some extent difficult to carry out at the present time, as there is a very diverse body of information (Rivas et al., 2015). Nowadays, some cities offer detailed information on the estimated energy savings, emissions reduction and implementation of measures in their SEAP, while others just give a very short description. In that sense, case studies referring to specific measures may be adequate to evaluate their effect. Along this line, Beccali et al. (2015) recently analyzed the adoption of LEDs to achieve the urban lighting energy saving proposed in Southern Italian municipalities' SEAPs, considering that the substitution of light sources alone was insufficient to achieve real economic benefits.

Table 4 also shows that the result estimates do not support the EKC hypothesis, as there are no significantly negative coefficients for $Y^{2}$ and $Y^{3}\left(\beta_{2}\right.$ and $\beta_{3}$ coefficients in [4]). Coefficients for $Y$ and $Y^{2}$ ( $\beta_{1}$ and $\beta_{2}$ coefficients in [4]), for total and residential estimates, and for $Y^{3}$ for residential estimates are positive and significant, which means that electricity is positive related to income. Therefore some of the reductions observed in electricity consumption in municipalities since 2008 may be related to income reductions due to the economic crisis. Meira et al. (2013) highlighted that $74.2 \%$ of a sample of 1,000 surveyed, about the response of Spanish society to climate change, stated being sure that less electricity was consumed because of the crisis. Therefore, an increase of electricity consumption may be expected as income grows. Municipalities' action plans may include efficiency measures to reduce electricity needs. Likewise, municipalities may also include policy measures to promote local renewable systems 
that enable consumers to produce their own renewable energy, such as, for example, solar systems. In that regard, municipalities' inhabitants will be motivated to selfproduce renewable electricity if this is cheaper than alternative supplies, and/or provide some level of independence (Kästel and Gilroy-Scott, 2015; Pillai et al., 2014; Schleicher-Tappeser, 2012). At that point, as stated in Kästel and Gilroy-Scott (2015), the ability to match supply and demand, and the national regulatory and technical requirements to connect to the grid, may be decisive success factors. Municipalities may facilitate the installation of local renewable systems by simplifying local regulations and introducing some fiscal incentives to reduce installation costs. Sánchez-Braza and Pablo-Romero (2014) show the positive effects of a municipality property tax bonus to promote the installation of solar-thermal energy systems in buildings, with this measure actually being included in some Spanish CM signatories' action plans.

Table 4 also shows that coefficients for $Y$ and $Y^{2}$ are not significant in public administration estimates, in all estimates, which means that public revenues, as they are measured in this study, have no effect on public administration electricity consumption. Perhaps, when the public income of a municipality increases, it may be expected that its electricity consumption also grows, but when this income reduces, it may be more difficult for a public administration to reduce its electricity consumption.

Additionally, the results show that population density has negative effects on the electricity consumption growth rate, as all estimated $D$ coefficients are negative and significant. These results seem to suggest that urbanization can generate agglomeration benefits that are environmentally effective, as stated in Zahran et al. (2008). In that regard, although the authors consider that agglomeration benefits are obtained mainly by transportation efficiency improvements, they also point out that these benefits may be obtained because of other reasons, such as collective savings when installing new energy systems for example.

Moreover, Table 4 shows that the size of the municipality negatively affects the electricity consumption growth. Therefore, as the size of the municipality increases, the per capita electricity consumption tends to be lower. Pablo-Romero et al. (2015a) find that the energy consumption per capita tends to decrease when the size of the municipality tends to increase in the $\mathrm{CM}$ signatories in Southern countries. Additionally, the authors find that the smallest cities have predicted smaller reductions per capita. Nevertheless, the estimated coefficients related to size for residential 
electricity consumption are not significant and nearly at zero, so municipality size may not be having an influence in this case.

\section{Conclusion and Policy Implications}

The $\mathrm{CM}$ is an initiative promoted by the European Commission as a voluntary agreement between local governments to reduce their $\mathrm{CO}_{2}$ emissions beyond the $20 \%$ target. With this initiative, municipalities are actively involved in a common strategy towards energy and environmental sustainability, and they take a more active role to commit to the European energy and climate targets. Signatory municipalities commit to implement specific action plans to show the way in which the municipality wants to reach the objectives of reducing pollution, usually by increasing energy efficiency and the use of renewable energy sources within their territories.

The evolution of electricity consumption in households, public administrations and the total related to income of municipalities are analyzed. The descriptive analysis shows differences between electricity consumption in signatory and non-signatory municipalities. In addition, differences are also observed between municipalities when size is considered, and between residential and public administration electricity consumption.

The relationships between electricity consumption in households, public administrations and totals and the income of municipalities are estimated by using a panel data model, including a set of control variables, including a variable indicating the membership, or not, of the CM. The estimations are obtained by using quadratic functions and cubic functions to allow a greater range and modeling flexibility.

Obtained results show that the CM is having a positive effect on the electricity consumption reductions, since the municipalities have greater rates of reduction of electricity consumption after signing the CM. Therefore, it may be considered that it may be appropriate to promote policies that incentivize the municipalities to join the $\mathrm{CM}$ and to develop their action plans, as this can reduce their electrical consumption.

The results also show differences in the coefficient values for $\mathrm{CM}$ as they refer to the electrical consumption of the residential sector or that of the Public Administrations, being greater in the first sector. Therefore, it could be appropriate to carry out a more 
advanced analysis to determine which applied measures are reducing electrical consumption to the greatest extent, taking into account the characteristics of the municipalities in which they are applied, with the purpose of guiding the municipalities in the policies to apply.

It is also shown from the total and residential estimations, that electricity is positively related to income. Therefore, some of the reductions observed in electricity consumption, since 2008, may be related to the income reductions due to the economic crisis, so it might be expected that the recovery from the crisis would also entail increases in electrical consumption. In this sense, the application of energy efficiency measures could be appropriate. Also, it could be appropriate to establish measures which promote the production and consumption of renewable energy in the homes and other buildings. This is why the establishment of national policies which facilitate the role of prosumers is very recommendable.

The results also reflect that population density and the size of the municipality have negative effects on electricity consumption growth. This is why the smaller cities or those with lower population density may have to make a greater effort to reduce their electricity consumption, establishing measures that allow economies of scale to be obtained as seems to be the case with the larger municipalities.

\section{Acknowledgements}

The first and third authors wish to acknowledge the financial support received from the ECO2014-56399-R Project of the Spanish Ministry of Economy and Competitiveness, the Cátedra de la Economía de la Energía y del Medio Ambiente (Chair of Energy and Environmental Economics) of the University of Seville, the Fundació Roger Torné, and from the SEJ-132 Research Group.

\section{References}

AAE, 2015. Datos Energéticos de Andalucía 2014. Agencia Andaluza de la Energía, Seville, Sapin.

Ahmed, K., Long, W., 2012. Environmental Kuznets curve and Pakistan: An empirical analysis. Procedia Economics and Finance 1, 4-13. 
Amorim, E.V., 2014. Sustainable Energy Action Plans: Project management intercomparison. Procedia Technology 16, 1183-1189.

Beccali, M., Bonomolo, M., Ciulla, G., Galatioto, A., Brano, V.L., 2015. Improvement of energy efficiency and quality of street lighting in South Italy as an action of Sustainable Energy Action Plans. The case study of Comiso (RG). Energy 92(3), 394-408.

Bhatt, V., Friley, P., Lee, J., 2010. Integrated energy and environmental systems analysis methodology for achieving low carbon cities. Journal of Renewable and Sustainable Energy 2, 1-19.

Bjelic, I.B., Ciric, R.M., 2014. Optimal distributed generation planning at a local level A review of Serbian renewable energy development. Renewable and Sustainable Energy Reviews 39, 79-86.

Brito, M.C., Lobato, K., Nunes, P., Serra, F., 2014. Sustainable energy systems in an imaginary island. Renewable and Sustainable Energy Reviews 37, 229-242.

Bulkeley, H., Broto, V.C., Edwards, G., 2012. Bringing climate change to the city: Towards low carbon urbanism? Local Environment 17(5), 545-551.

Bulkeley, H., Kern, K., 2006. Local government and the governing of climate change in Germany and the UK. Urban Studies 43(12), 2237-2259.

Caraiani, C., Lungu, C.I., Dascălu, C., 2015. Energy consumption and GDP causality: A three-step analysis for emerging European countries. Renewable and Sustainable Energy Reviews 44, 198-210.

Cerutti, A.K., Iancu, A., Janssens-Maenhout, G., Melica, G., Paina, F., Bertoldi, P., 2013. Covenant of Mayors in Figures: 5-Years Assessment. JRC Science and Policy Reports, European Commission. Publications Office of the European Union, Luxembourg.

Christoforidis, G.C., Chatzisavvas, K.C., Lazarou, S., Parisses, C., 2013. Covenant of Mayors initiative-Public perception issues and barriers in Greece. Energy Policy 60, 643-655.

Covenant of Mayors, 2016. Covenant of Mayors signatories.www.covenantofmayors.eu

Dall'O, G., Norese, M.F., Galante, A., Novello, C., 2013. A multi-criteria methodology to support public administration decision making concerning sustainable energy action plans. Energies 6(8), 4308-4330.

Damsø, T., Kjær, T., Christensen, T.B., 2016. Local climate action plans in climate change mitigation-Examining the case of Denmark. Energy Policy 89, 74-83.

Dawson, R.J., Wyckmans, A., Feliu, E., Dobson, S., Koehler, J., Heidrich, O., 2014. Section VI. Understanding cities: The way forward for integrated assessment, in: Dawson et al., (Eds.), Understanding Cities: Advances in Integrated Assessment of Urban Sustainability, Final Report of COST Action TU0902K. Centre for Earth Systems Engineering Research (CESER), Newcastle University, Newcastle, pp. 199213.

De la Fuente, A. 2008., Una Función de Producción Translog para las Regiones Españolas: Notas Preliminares. Documento de Trabajo D-2008-06. Dirección General de Presupuestos, Ministerio de Economía y Hacienda, Madrid 
Di Leo, S., Pietrapertosa, F., Loperte, S., Salvia, M., Cosmi, C., 2015. Energy systems modelling to support key strategic decisions in energy and climate change at regional scale. Renewable and Sustainable Energy Reviews 48, 394-414.

Dinda S., 2004. Environmental Kuznets curve hypothesis: A survey. Ecological Economics 49(4), 431-455.

Doukas, H., Papadopoulou, A., Savvakis, N., Tsoutsos, T., Psarras, J., 2012. Assessing energy sustainability of rural communities using Principal Component Analysis. Renewable and Sustainable Energy Reviews 16(4), 1949-1957.

European Parliament and the Council, 2009. Directive 2009/28/EC of the European Parliament and of the Council of 23 April 2009 on the Promotion of the Use of Energy from Renewable Sources and Amending and Subsequently Repealing Directives 2001/77/EC and 2003/30/EC. Official Journal of the European Union L 140, Luxembourg, pp. 16-62.

Famoso, F., Lanzafame, R., Monforte, P., Scandura, P.F., 2015. Analysis of the Covenant of Mayors Initiative in Sicily. Energy Procedia 81, 482-492.

Ferguson, R., Wilkinson, W., Hill, R., 2000. Electricity use and economic development. Energy policy 28(13), 923-934.

Fünfgeld, H., 2015. Facilitating local climate change adaptation through transnational municipal networks. Current Opinion in Environmental Sustainability 12, 67-73.

Galante, A., Pasetti, G., 2012. A methodology for evaluating the potential energy savings of retrofitting residential building stocks. Sustainable Cities and Society 4, $12-21$.

Gertler, P. J., Shelef, O., Wolfram, C. D., Fuchs, A. 2016. The Demand for EnergyUsing Assets among the World's Rising Middle Classes. The American Economic Review 106(6), 1366-1401.

González-Limón, J.M., Pablo-Romero, M.P., Sánchez-Braza, A., 2013. Understanding local adoption of tax credits to promote solar-thermal energy: Spanish municipalities' case. Energy 62, 277-284.

Greene, W., 2000. Econometric Analysis, fourth edition. Prentice Hall, Upper Saddle River, New Jersey.

Grossman, G., Krueger, A., 1991. Environmental Impacts of a North American Free Trade Agreement. Working Paper WP3914. National Bureau of Economic Research, Cambridge, Massachusetts.

Hakelberg, L., 2014. Governance by diffusion: Transnational municipal networks and the spread of local climate strategies in Europe. Global Environmental Politics 14(1), 107-129.

Hallegatte, S., Henriet, F., Corfee-Morlot, J., 2011. The economics of climate change impacts and policy benefits at city scale: A conceptual framework. Climatic Change 104(1), 51-87.

He, J., Richard, P., 2010. Environmental Kuznets curve for $\mathrm{CO}_{2}$ in Canada. Ecological Economics 69(5), 1083-1093.

Heidrich, O., Dawson, R.J., Reckien, D., Walsh, C.L., 2013. Assessment of the climate preparedness of 30 urban areas in the UK. Climatic Change 120(4), 771-784. 
Heidrich, O., Reckien, D., Olazabal, M., Foley, A., Salvia, M., de Gregorio Hurtado, S., Orrug, H., Flacke, J., Geneletti, D., Pietrapertosa, F., Hamann, J.J.-P., Tiwary, A., Feliu, E., Dawson, R.J., 2016. National climate policies across Europe and their impacts on cities strategies. Journal of Environmental Management 168, 36-45.

Iancu, A., Martelli, S., Cerutti, A.K., Janssens-Maenhout, G., Melica, G., Rivas-Calvete, S., Kona, A., Zancanella, P., Bertoldi, P., 2015. A harmonised dataset of greenhouse gas emissions inventories from cities under the EU Covenant of Mayors initiative. Earth System Science Data Discuss 8, 461-507.

IDAE, 2007. Estrategia de Ahorro y Eficiencia Energética en España 2004-2012. Plan de Acción 2008-2012. Instituto para la Diversificación y Ahorro de la Energía, Madrid.

IDAE, 2011. Análisis del Consumo Energético del Sector Residencial en España. Instituto para la Diversificación y Ahorro de la Energía, Madrid.

Jadraque, E., Ordoñez, J., Espín, A., 2011. Development of an energy model for the residential sector: Electricity consumption in Andalusia, Spain. Energy and Buildings 43(6), 1315-1321.

Jones, D.W., 1991. How urbanization affects energy-use in developing countries. Energy Policy 19(7), 621-630.

Karanfil, F., Li, Y., 2015. Electricity consumption and economic growth: exploring panel-specific differences. Energy Policy 82, 264-277.

Kästel, P., Gilroy-Scott, B., 2015. Economics of pooling small local electricity prosumers - LCOE \& self-consumption. Renewable and Sustainable Energy Reviews 51, 718-729.

Kaufmann, R.K., Davidsdottir, B., Garnham, S., Pauly, P., 1998. The determinants of atmospheric $\mathrm{SO}_{2}$ concentrations: Reconsidering the environmental Kuznets curve. Ecological Economics 25(2), 209-220.

Kona, A., Melica, G., Rivas, S., Zancanella, P., Iancu, A., Gabrielaitiene, I., Saheb, Y., Janssens-Manhout, G., Bertoldi, P., 2015. The Covenant of Mayors in Figures and Performance Indicators: 6-Year Assessment. JRC Science and Policy Reports, European Commission, Publications Office of the European Union, Luxembourg.

Kyriakarakos, G., Patlitzianas, K., Damasiotis, M., Papastefanakis, D., 2014. A fuzzy cognitive maps decision support system for renewables local planning. Renewable and Sustainable Energy Reviews 39, 209-222.

Labaeye, A, Sauer, T., 2013. City Networks and the Socio-Ecological Transition - A European Inventory. Working paper $\mathrm{N}^{\mathrm{o}}$. 27. Welfare, Wealth and Work for Europe. http://www.foreurope.eu/

Leach, G., 1992. The energy transition. Energy Policy 20(2), 116-123.

Li, K., Lin, B., 2015. Impacts of urbanization and industrialization on energy consumption $/ \mathrm{CO}_{2}$ emissions: Does the level of development matter? Renewable and Sustainable Energy Reviews 52, 1107-1122.

Lombardi, M., Rana, R., Pazienza, P., Tricase, C., 2014. The European policy for the sustainability of urban areas and the "Covenant of Mayors" initiative: A case study, in: Salomone, R., Saija, G., (Eds.), Pathways to Environmental Sustainability. Springer International Publishing, Cham, pp. 183-192. 
Luzzati, T., Orsini, M., 2009. Investigating the energy-environmental Kuznets curve. Energy 34(3), 291-300.

Lybæk, R., Kjær, T., 2015. Municipalities as facilitators, regulators and energy consumers for enhancing the dissemination of biogas technology in Denmark. International Journal of Sustainable Energy Planning and Management 8, $17-30$.

Ma, B., 2015. Does urbanization affect energy intensities across provinces in China? Long-run elasticities estimation using dynamic panels with heterogeneous slopes. Energy Economics 49, 390-401.

McNeil, M.A., Letschert, V.E., 2010. Modeling diffusion of electrical appliances in the residential sector. Energy and Buildings 42(6), 783-790.

Magni, F., Maragno, D., 2014. Sustainable Energy Action Plans (SEAP) and the Climate Plans: New tools for local environmental planning, in: ECTP-CEU (Eds.), Spatial Planning \& Energy - Young Planners Workshop. European Council of Spatial Planners and Conseil Européen des Urbanistes, Brussels, pp. 33-54.

Marinakis, V., Papadopoulou, A.G., Siskos, J., Psarras, J., 2012. Sustainable energy communities: A methodological framework for the support of local and regional stakeholders - Management of energy sources \& systems. Proceedings of the 23rd National Conference of the Hellenic Operational Research Society (HELORS), Athens.

Marinakis, V., Papadopoulou, A.G., Doukas, H., Psarras, J., 2015a. A web tool for sustainable energy communities. International Journal of Information and Decision Sciences 7(1), 18-31.

Marinakis, V., Papadopoulou, A.G., Psarras, J., 2015b. Local communities towards a sustainable energy future: Needs and priorities. International Journal of Sustainable Energy, ahead-of-print.

Mårtensson, K., Westerberg, K., 2007. How to transform local energy systems towards bioenergy? Three strategy models for transformation. Energy Policy 35(12), 60956105.

Martos, A., Pacheco-Torres, R., Ordóñez, J., Jadraque-Gago, E., 2016. Towards successful environmental performance of sustainable cities: Intervening sectors. A review. Renewable and Sustainable Energy Reviews 57, 479-495.

Meira, P.A. (Dir.), Arto, M., Heras, F., Iglesias, L., Lorenzo, J.J., Montero, P., 2013. La Respuesta de la Sociedad Española ante el Cambio Climático - 2013. Instituto de Prevención Salud y Medio Ambiente, Fundación Mapfre, Madrid.

Melica, G., Bertoldi, P., Kona, A., Rivas, S., Zancanella, P., Janssens-Maenhout, G., Cerutti, A.K., Iancu, A., Ganisheva, K., 2014. The Covenant of Mayor initiative: An assessment and evaluation. ACEEE Summer Study on Energy Efficiency in Buildings.American Council for an Energy-Efficient Economy, Washington D.C.

Menegaki, A.N., 2014. On energy consumption and GDP studies; A meta-analysis of the last two decades. Renewable and Sustainable Energy Reviews 29, 31-36.

Mirakyan, A., De Guio, R., 2013. Integrated energy planning in cities and territories: a review of methods and tools. Renewable and Sustainable Energy Reviews 22, 289297. 
Narayan, P.K., Narayan, S., 2010. Carbon dioxide emissions and economic growth: Panel data evidence from developing countries. Energy Policy 38(1), 661-666.

Narayan, P.K., Prasad, A., 2008. Electricity consumption-real GDP causality nexus: Evidence from a bootstrapped causality test for 30 OECD countries. Energy Policy 36(2), 910-918.

Neves, A.R., Leal, V., 2010. Energy sustainability indicators for local energy planning: Review of current practices and derivation of a new framework. Renewable and Sustainable Energy Reviews 14(9), 2723-2735.

Olazabal, M., De Gregorio Hurtado, S., Olazabal, E., Pietrapertosa, F., Salvia, M., Geneletti, D., D’Alonzo, V., Feliú, E., Di Leo, S., Reckien D., 2014. How Italian and Spanish Cities Are Tackling Climate Change? A Local Comparative Study. BC3 Working Paper Series 2014-3. Basque Centre for Climate Change, Bilbao.

Oliver-Solà, J., Armero, M., De Foix, B.M., Rieradevall, J., 2013. Energy and environmental evaluation of municipal facilities: Case study in the province of Barcelona. Energy Policy 61, 920-930.

Pablo-Romero, M.P., De Jesús, J. (2016). Economic growth and energy consumption: The Energy-Environmental Kuznets Curve for Latin America and the Caribbean. Renewable and Sustainable Energy Reviews 60, 1343-1350.

Pablo-Romero, M.P., Sánchez-Braza, A., 2015. Productive energy use and economic growth: Energy, physical and human capital relationships. Energy Economics 49, 420-429.

Pablo-Romero, M.P., Pozo-Barajas, R., Sánchez-Braza, A., 2015a. Understanding local $\mathrm{CO}_{2}$ emissions reduction targets. Renewable and Sustainable Energy Reviews 48, 347-355.

Pablo-Romero, M.P., Sánchez-Braza, A., González-Limón, J.M., 2015b. Covenant of Mayors: Reasons for being an environmentally and energy friendly municipality. Review of Policy Research 32(5), 576-599.

Pasimeni, M.R., Petrosillo, I., Aretano, R., Semeraro, T., De Marco, A., Zaccarelli, N., Zurlini, G., 2014. Scales, strategies and actions for effective energy planning: A review. Energy Policy 65, 165-174.

Pesaran, M., 2004. General Diagnostic Tests for Cross Section Dependence in Panels. Cambridge Working Papers WP0435. Faculty of Economics, University of Cambridge, Cambridge.

Piaggio, M., Padilla, E., 2012. $\mathrm{CO}_{2}$ emissions and economic activity: Heterogeneity across countries and non-stationary series. Energy Policy 40, 370-381.

Pillai, G.G., Putrus, G.A., Georgitsioti, T., Pearsall, N.M., 2014. Near-term economic benefits from grid-connected residential PV (photovoltaic) systems. Energy 68, 832843.

Pita, M.F., Orozco, G., 2012. La dimensión territorial del consumo eléctrico en Andalucía a escalas detalladas. Nimbus 29-30, 549-561.

Poumanyvong, P., Kaneko, S., Dhakal, S., 2012. Impacts of urbanization on national transport and road energy use: Evidence from low, middle and high income countries. Energy Policy 46, 268-277. 
Prasad, R.D., Bansal, R.C., Raturi, A., 2014. Multi-faceted energy planning: A review. Renewable and Sustainable Energy Reviews 38, 686-699.

Radulovic, D., Skok, S., Kirincic, V., 2011. Energy efficiency public lighting management in the cities. Energy 36(4), 1908-1915.

Reckien, D., Flacke, J., Dawson, R.J., Heidrich, O., Olazabal, M., Foley, A., Hamann, J. J.-P., Orru, H., Salvia, M., De Gregorio Hurtado, S., Geneletti, D., Pietrapertosa, F., 2014. Climate change response in Europe: What's the reality? Analysis of adaptation and mitigation plans from 200 urban areas in 11 countries. Climatic Change 122(1), 331-340.

Rivas S, Melica G, Kona A, Zancanella P, Serrenho T, Iancu A, Koffi, B., Gabrielaitiene, I., Janssens-Maenhout, G., Bertoldi P., 2015. The Covenant of Mayors: In-depth Analysis of Sustainable Energy Actions Plans. JRC Science and Policy Reports, European Commission, Publications Office of the European Union, Luxembourg.

Saboori B, Sulaiman J., 2013. Environmental degradation, economic growth and energy consumption: Evidence of the environmental Kuznets curve in Malaysia. Energy Policy 60, 892-905.

Sánchez-Braza, A., Pablo-Romero, M.P., 2014. Evaluation of property tax bonus to promote solar thermal systems in Andalusia (Spain). Energy Policy 67, 832-843.

Schleicher-Tappeser, R., 2012. How renewables will change electricity markets in the next five years. Energy Policy 48, 64-75.

Selden, T., Song, D., 1994. Environmental quality and development: Is there a Kuznets curve for air pollution emissions? Journal of Environmental Economics and Management 27(2), 147-162.

SIMA, 2015. Sistema de Información Multiterritorial de Andalucía. Junta de Andalucía, Sevilla.

Sovacool, B.K., 2011. An international comparison of four polycentric approaches to climate and energy governance. Energy Policy 39(6), 3832-3844.

Stern, D., 2014. The Environmental Kuznets Curve: A Primer. CCEP Working Paper 1404, Centre for Climate Economic \& Policy, Crawford School of Public Policy, The Australian National University.

Suri V, Chapman D., 1998. Economic growth, trade and energy: implications for the environmental Kuznets Curve. Ecological Economics 25, 195-208

van der Schoor, T., Scholtens, B., 2015. Power to the people: Local community initiatives and the transition to sustainable energy. Renewable and Sustainable Energy Reviews 43, 666-675.

Viardot, E., 2013. The role of cooperatives in overcoming the barriers to adoption of renewable energy. Energy Policy 63, 756-764.

Walker, G., Devine-Wright, P., Hunter, S., High, H., Evans, B., 2010. Trust and community: Exploring the meanings, contexts and dynamics of community renewable energy. Energy Policy 38(6), 2655-2663.

Wooldridge, J., 2002. Econometric Analysis of Cross Section and Panel Data. MIT Press, Cambridge, Massachusetts. 
Yin, H., Zhou, H., Zhu, K., 2016. Long-and short-run elasticities of residential electricity consumption in China: a partial adjustment model with panel data. Applied Economics 48(28), 2587-2599.

Yoo, S.H., Lee, J.S., 2010. Electricity consumption and economic growth: a crosscountry analysis. Energy Policy 38(1), 622-625.

Zahran, S., Grover, H., Brody, S.D., Vedlitz, A., 2008. Risk, stress, and capacity explaining metropolitan commitment to climate protection. Urban Affairs Review 43(4), 447-474.

Zhang, M., Song, Y., Li, P., Li, H., 2016. Study on affecting factors of residential energy consumption in urban and rural Jiangsu. Renewable and Sustainable Energy Reviews 53, 330-337.

Zilio M, Recalde M., 2011. GDP and environment pressure: The role of energy in Latin America and the Caribbean. Energy Policy 39, 7941-7949 
Table 1.

Studies that analyzes the toolkits used in the preparation of SEAPs in CM signatories

\begin{tabular}{|l|l|l|}
\hline Study & Toolkit & Applied in \\
\hline Galante y Pasetti (2012) & $\begin{array}{l}\text { Potential energy savings of } \\
\text { energy retrofits of existing } \\
\text { building assets }\end{array}$ & $\begin{array}{l}\text { Municipalities in the province of } \\
\text { Milan }\end{array}$ \\
\hline Dall'O et al. (2013) & $\begin{array}{l}\text { Multi-criteria analysis based on } \\
\text { the ELECTRE III to support } \\
\text { local public administrators } \\
\text { method }\end{array}$ & $\begin{array}{l}\text { Municipality in the Lombardy } \\
\text { region }\end{array}$ \\
\hline Bjelic and Ciric (2014) & $\begin{array}{l}\text { HOMER for the configuration } \\
\text { plan of the municipal microgrids }\end{array}$ & Municipalities in Serbia \\
\hline Kyriakarakos et al. (2014). & $\begin{array}{l}\text { Fuzzy cognitive maps on a web } \\
\text { platform }\end{array}$ & $\begin{array}{l}\text { Crete Island } \\
\text { framework realized into web } \\
\text { application }\end{array}$ \\
\hline Marinakis et al (2015), & $\begin{array}{l}\text { Anteractive Croatia, Greece and } \\
\text { Portugal }\end{array}$ \\
\hline
\end{tabular}


Table 2.

Studies that analyzes municipalities' experiences in joining CM or developing their SEAPs.

\begin{tabular}{|c|c|c|}
\hline Study & Type of Study & CM Municipalities \\
\hline Doukas et al. (2012) & $\begin{array}{l}\text { Assess communities' energy } \\
\text { sustainability }\end{array}$ & $\begin{array}{l}\text { Mountainous and agricultural } \\
\text { communities and islands }\end{array}$ \\
\hline Christoforidis et al (2013) & Barriers for signing $\mathrm{CM}$ & Greece municipalities \\
\hline Oliver-Solà et al. (2013) & $\begin{array}{l}\text { Analyzes the energy } \\
\text { consumption and emissions of } \\
\text { the municipal service facilities }\end{array}$ & Barcelona \\
\hline Heidrich et al. (2013) & $\begin{array}{l}\text { Analyze the adaptation and } \\
\text { mitigation action plans }\end{array}$ & $\begin{array}{l}30 \text { urban areas of UK (not all } \\
\mathrm{CM} \text { signatories) }\end{array}$ \\
\hline Lombardi et al. (2014) & $\begin{array}{l}\text { Methodology used for the } \\
\text { elaboration of the SEAPs }\end{array}$ & $\begin{array}{lll}6 \quad \text { province } & \text { of } & \text { Foggia } \\
\text { municipalities } & & \end{array}$ \\
\hline Magni and Maragno (2014) & $\begin{array}{l}\text { Describe the SEAPs and define a } \\
\text { study for a Local Action Plan for } \\
\text { Climate }\end{array}$ & $\begin{array}{l}\text { Italy municipalities and Province } \\
\text { of Rovigo }\end{array}$ \\
\hline Famoso et al. (2015) & Describe the CM initiative & Sicily \\
\hline Pablo-Romero et al (2015) & $\begin{array}{l}\text { Factors influencing the decision } \\
\text { to join } \mathrm{CM}\end{array}$ & Spanish municipalities \\
\hline Marinakis et al. (2015) & $\begin{array}{l}\text { Local communities' needs to } \\
\text { identify the parameters used in } \\
\text { SEAPs }\end{array}$ & $\begin{array}{l}\text { Rural communities from Austria, } \\
\text { Croatia, Greece and Portugal }\end{array}$ \\
\hline Rivas et al. (2015) & Analysis of the SEAPs & $\begin{array}{l}25 \text { municipalities from different } \\
\text { EU Member }\end{array}$ \\
\hline Damsø et al. (2016) & $\begin{array}{l}\text { Examine the local climate action } \\
\text { plans }\end{array}$ & $\begin{array}{l}\text { Denmark municipalities (not all } \\
\text { CM signatories) }\end{array}$ \\
\hline
\end{tabular}


Table 3.

Studies that evaluated the evolution of CM signatories and the main questions related to the SEAP objectives.

\begin{tabular}{|l|l|}
\hline Study & Type of Study \\
\hline Cerutti et al (2013) & Main figures of CM from a five years perspective \\
\hline Amorim (2014) & Overview of existing methodologies of SEAPs \\
\hline Melica et al (2014) & Assessment and evaluation of CM \\
\hline Kona et al (2015) & Main figures of CM from a six years perspective \\
\hline Iancu et al. (2015) & Collection of emission inventories for CM signatories \\
\hline Pablo-Romero et al. (2015) & $\begin{array}{l}\text { Relate } \mathrm{CO}_{2} \text { emissions reduction targets in SEAPs with some } \\
\text { indicators }\end{array}$ \\
\hline
\end{tabular}


Table 4

Estimate results

\begin{tabular}{|c|c|c|c|c|c|c|c|c|c|}
\hline & \multicolumn{2}{|c|}{$\begin{array}{c}\text { FGLS } \\
\begin{array}{c}\text { Total electricity } \\
\text { consumption }\end{array}\end{array}$} & \multirow{2}{*}{$\begin{array}{c}\text { GMM } \\
\begin{array}{c}\text { Total } \\
\text { electricity } \\
\text { consumption }\end{array} \\
\text { Squared }\end{array}$} & \multicolumn{2}{|c|}{$\begin{array}{c}\text { FGLS } \\
\begin{array}{c}\text { Residential electricity } \\
\text { consumption }\end{array}\end{array}$} & \multirow{2}{*}{$\begin{array}{c}\text { GMM } \\
\begin{array}{c}\text { Residential } \\
\text { electricity } \\
\text { consumption }\end{array} \\
\text { Squared }\end{array}$} & \multicolumn{2}{|c|}{$\begin{array}{c}\text { FGLS } \\
\text { Public administration } \\
\text { electricity consumption }\end{array}$} & \multirow{2}{*}{$\begin{array}{c}\text { GMM } \\
\begin{array}{c}\text { Public } \\
\text { administration } \\
\text { electricity } \\
\text { consumption }\end{array} \\
\text { Squared }\end{array}$} \\
\hline & Squared & Cubic & & Squared & Cubic & & Squared & Cubic & \\
\hline $\boldsymbol{Y}$ & $\begin{array}{c}0.157^{* * *} \\
(0.007)\end{array}$ & $\begin{array}{c}0.157 * * * \\
(0.008)\end{array}$ & $\begin{array}{c}0.124 * * * \\
(0.023)\end{array}$ & $\begin{array}{c}0.054^{* * *} \\
(0.008)\end{array}$ & $\begin{array}{c}0.036^{* * *} \\
(0.008)\end{array}$ & $\begin{array}{l}0.025^{* *} \\
(0.009)\end{array}$ & $\begin{array}{c}0.005 \\
(0.003)\end{array}$ & $\begin{array}{c}0.002 \\
(0.004)\end{array}$ & $\begin{array}{c}0.010 \\
(0.014)\end{array}$ \\
\hline$Y^{2}$ & $\begin{array}{c}0.078^{* * *} \\
(0.007)\end{array}$ & $\begin{array}{c}0.077 * * * \\
(0.008)\end{array}$ & $\begin{array}{c}0.057 * * * \\
(0.011)\end{array}$ & $\begin{array}{c}0.100 * * * \\
(0.008)\end{array}$ & $\begin{array}{c}0.138 * * * \\
(0.009)\end{array}$ & $\begin{array}{l}0.056^{* * * *} \\
(0.018)\end{array}$ & $\begin{array}{l}-0.005 \\
(0.004)\end{array}$ & $\begin{array}{l}-0.009^{*} \\
(0.005)\end{array}$ & $\begin{array}{l}-0.004 \\
(0.009)\end{array}$ \\
\hline$Y^{3}$ & - & $\begin{array}{l}-0.001 \\
(0.005)\end{array}$ & & - & $\begin{array}{c}0.039 * * * \\
(0.005)\end{array}$ & & - & $\begin{array}{c}0.005 \\
(0.005)\end{array}$ & \\
\hline$C M$ & $\begin{array}{c}-0.013 * * * \\
(0.002)\end{array}$ & $\begin{array}{c}-0.013 * * * \\
(0.002)\end{array}$ & $\begin{array}{c}-0.010^{* * *} \\
(0.004)\end{array}$ & $\begin{array}{c}-0.032^{* * *} \\
(0.002)\end{array}$ & $\begin{array}{c}-0.030^{* * *} \\
(0.002)\end{array}$ & $\begin{array}{l}-0.024 * * * \\
(0.004)\end{array}$ & $\begin{array}{c}-0.019 * * * \\
(0.002)\end{array}$ & $\begin{array}{c}-0.019 * * * \\
(0.002)\end{array}$ & $\begin{array}{c}-0.028 * * * \\
(0.006)\end{array}$ \\
\hline$D$ & $\begin{array}{c}-0.661 * * * \\
(0.024)\end{array}$ & $\begin{array}{c}-0.661 * * * \\
(0.024)\end{array}$ & $\begin{array}{c}-0.787 * * * \\
(0.054)\end{array}$ & $\begin{array}{c}-0.607 * * * \\
(0.026)\end{array}$ & $\begin{array}{c}-0.607 * * * \\
(0.026)\end{array}$ & $\begin{array}{l}-0.602 \\
(0.002)\end{array}$ & $\begin{array}{c}-0.753 * * * \\
(0.032)\end{array}$ & $\begin{array}{c}-0.752 * * * \\
(0.032)\end{array}$ & $\begin{array}{c}-0.726 * * * \\
(0.058)\end{array}$ \\
\hline$S E$ & $\begin{array}{c}-0.007 * * * \\
(0.001)\end{array}$ & $\begin{array}{c}-0.007^{* * *} \\
(0.001)\end{array}$ & $\begin{array}{c}-0.006^{* * *} \\
(0.002)\end{array}$ & $\begin{array}{l}-0.000 \\
(0.001)\end{array}$ & $\begin{array}{l}-0.000 \\
(0.001)\end{array}$ & $\begin{array}{l}-0.001 \\
(0.002)\end{array}$ & $\begin{array}{c}-0.004 * * * \\
(0.001)\end{array}$ & $\begin{array}{c}-0.004 * * * \\
(0.001)\end{array}$ & $\begin{array}{c}-0.007 * * * \\
(0.002)\end{array}$ \\
\hline $\begin{array}{c}\text { Kleibergen-Paap rk } \\
\text { Underidentification } \\
\text { test }\end{array}$ & & & $755.930 * * *$ & & & $686.032 * * *$ & & & $410.514 * * *$ \\
\hline $\begin{array}{c}\text { Kleibergen-Paap rk } \\
\text { Weak } \\
\text { identification test }\end{array}$ & & & $1103.802^{* * *}$ & & & $730.349^{* * *}$ & & & $357.937 * * *$ \\
\hline $\begin{array}{l}\text { Cragg-Donald } \\
\text { Weak } \\
\text { identification test }\end{array}$ & & & $2562.641^{* * *}$ & & & $2213.092^{* * *}$ & & & $803.666 * * *$ \\
\hline $\begin{array}{c}\text { Hansen } \\
\text { Overidentification } \\
\text { test }\end{array}$ & & & 2.241 & & & 0.783 & & & 0.025 \\
\hline
\end{tabular}

Note: All estimated include time dummies. Standard errors are shown in parenthesis, *** denotes significant level at $1 \%, * *$ for $5 \%$ and $*$ for $10 \%$. 
Table 5

Variance inflation factors

\begin{tabular}{|c|c|c|c|c|c|c|}
\hline & \multicolumn{2}{|c|}{$\begin{array}{c}\text { Total electricity } \\
\text { consumption }\end{array}$} & \multicolumn{2}{c|}{$\begin{array}{c}\text { Residential electricity } \\
\text { consumption }\end{array}$} & \multicolumn{2}{c|}{$\begin{array}{c}\text { Public administration } \\
\text { electricity consumption }\end{array}$} \\
\hline Variable & VIF & $\begin{array}{c}\text { Tolerance } \\
\text { indicator: } \\
\text { 1/VIF }\end{array}$ & VIF & $\begin{array}{c}\text { Tolerance } \\
\text { indicator: } \\
\text { 1/VIF }\end{array}$ & VIF & $\begin{array}{c}\text { Tolerance } \\
\text { indicator: } \\
\text { 1/VIF }\end{array}$ \\
\hline $\boldsymbol{Y}$ & 4.89 & 0.204386 & 3.32 & 0.301255 & 2.11 & 0.473223 \\
\hline $\boldsymbol{Y}^{2}$ & 1.36 & 0.733324 & 1.33 & 0.751313 & 1.68 & 0.595502 \\
\hline $\boldsymbol{C M}$ & 2.87 & 0.348730 & 2.51 & 0.399068 & 2.98 & 0.335549 \\
\hline $\boldsymbol{D}$ & 1.39 & 0.719271 & 1.28 & 0.779585 & 1.23 & 0.812107 \\
\hline $\boldsymbol{S E}$ & 4.57 & 0.218818 & 4.47 & 0.223713 & 4.07 & 0.245700 \\
\hline dut3 & 1.64 & 0.609197 & 1.63 & 0.614770 & 1.66 & 0.601739 \\
\hline dut4 & 1.78 & 0.562471 & 1.50 & 0.666716 & 1.64 & 0.608172 \\
\hline dut5 & 1.65 & 0.605043 & 1.61 & 0.619710 & 1.63 & 0.612478 \\
\hline dut6 & 1.91 & 0.522589 & 1.48 & 0.674383 & 1.55 & 0.643659 \\
\hline dut7 & 2.69 & 0.371320 & 1.75 & 0.570054 & 1.60 & 0.625507 \\
\hline dut8 & 1.67 & 0.598194 & 2.23 & 0.448907 & 1.88 & 0.532304 \\
\hline dut9 & 2.68 & 0.372825 & 1.59 & 0.630607 & 1.93 & 0.519223 \\
\hline dut10 & 1.94 & 0.514384 & 1.60 & 0.624275 & 2.03 & 0.492005 \\
\hline dut11 & 2.11 & 0.473789 & 1.45 & 0.689735 & 2.02 & 0.494584 \\
\hline dut12 & 2.75 & 0.364184 & 1.86 & 0.537234 & 1.60 & 0.625507 \\
\hline
\end{tabular}




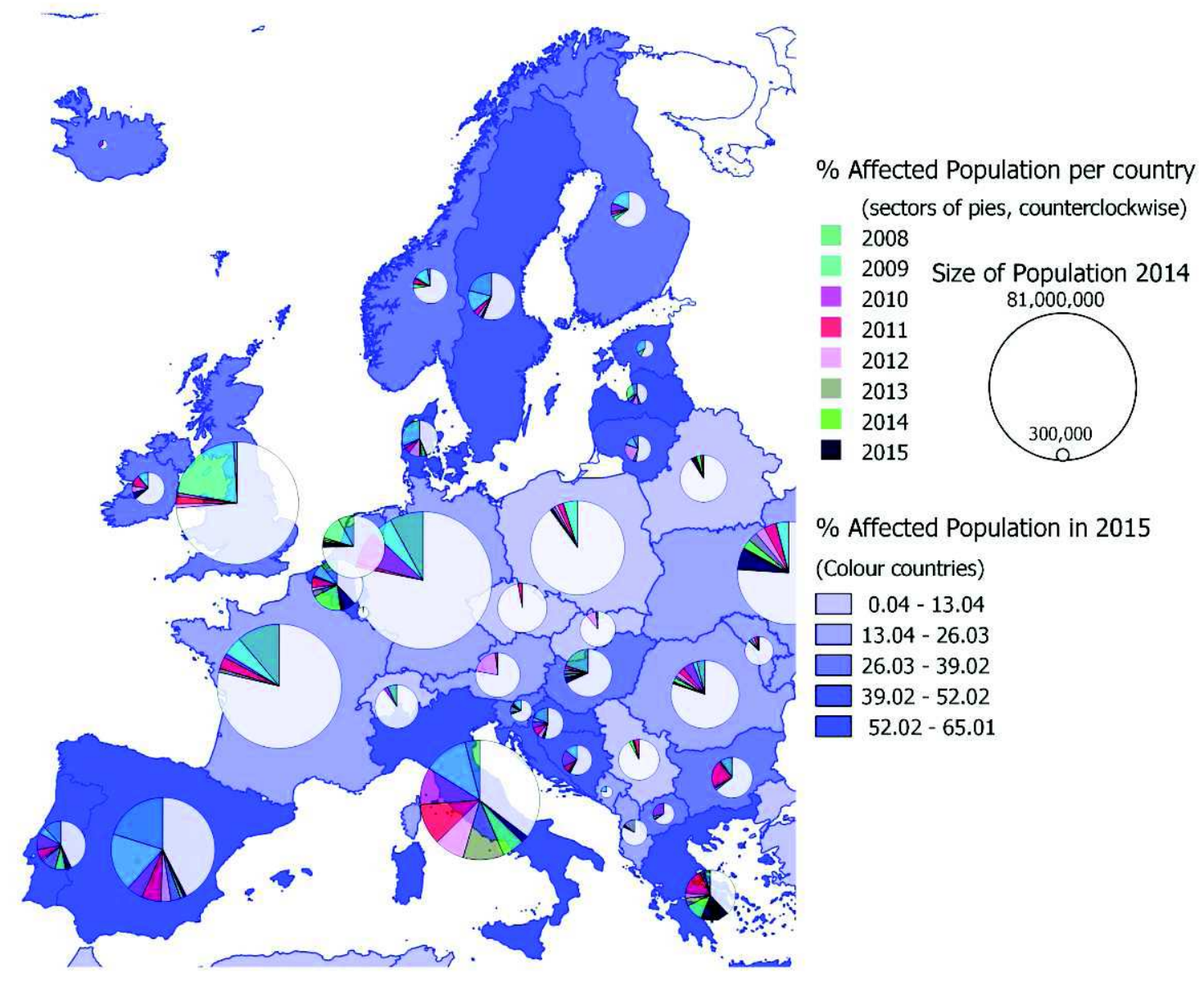

Fig. 1. Population affected by $\mathrm{CM}$ in Europe. 


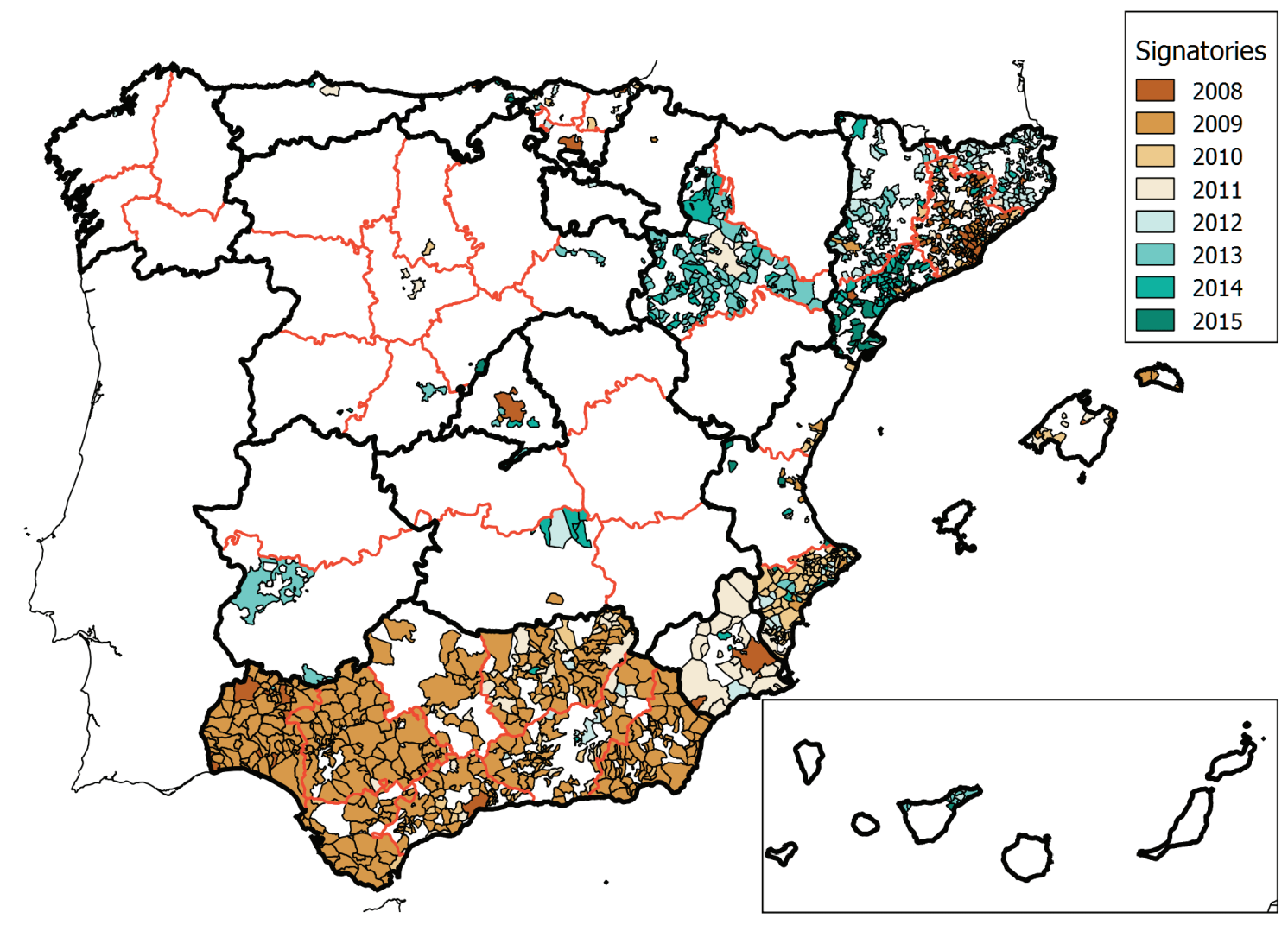

Fig. 2. Covenant of Mayors signatories in Spain. 


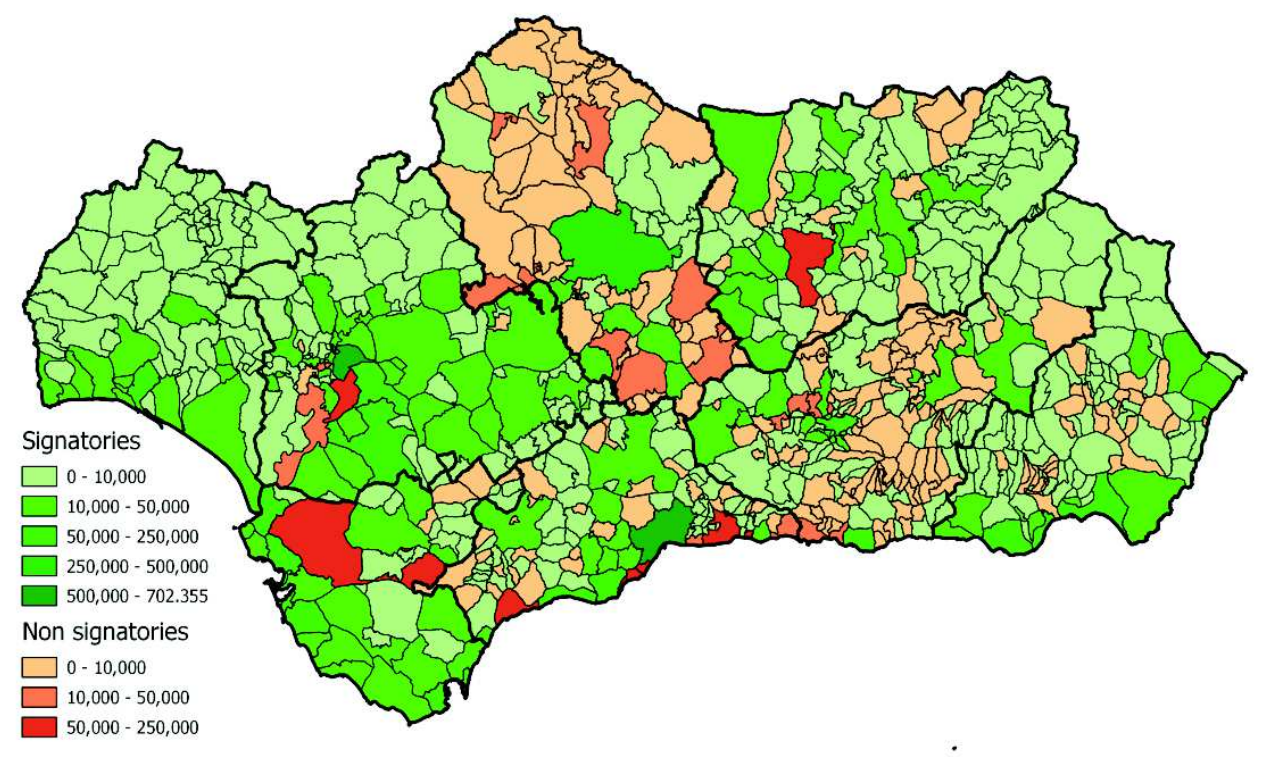

Fig. 3. CM signatories and non-signatories in Andalusia until December 2012. 


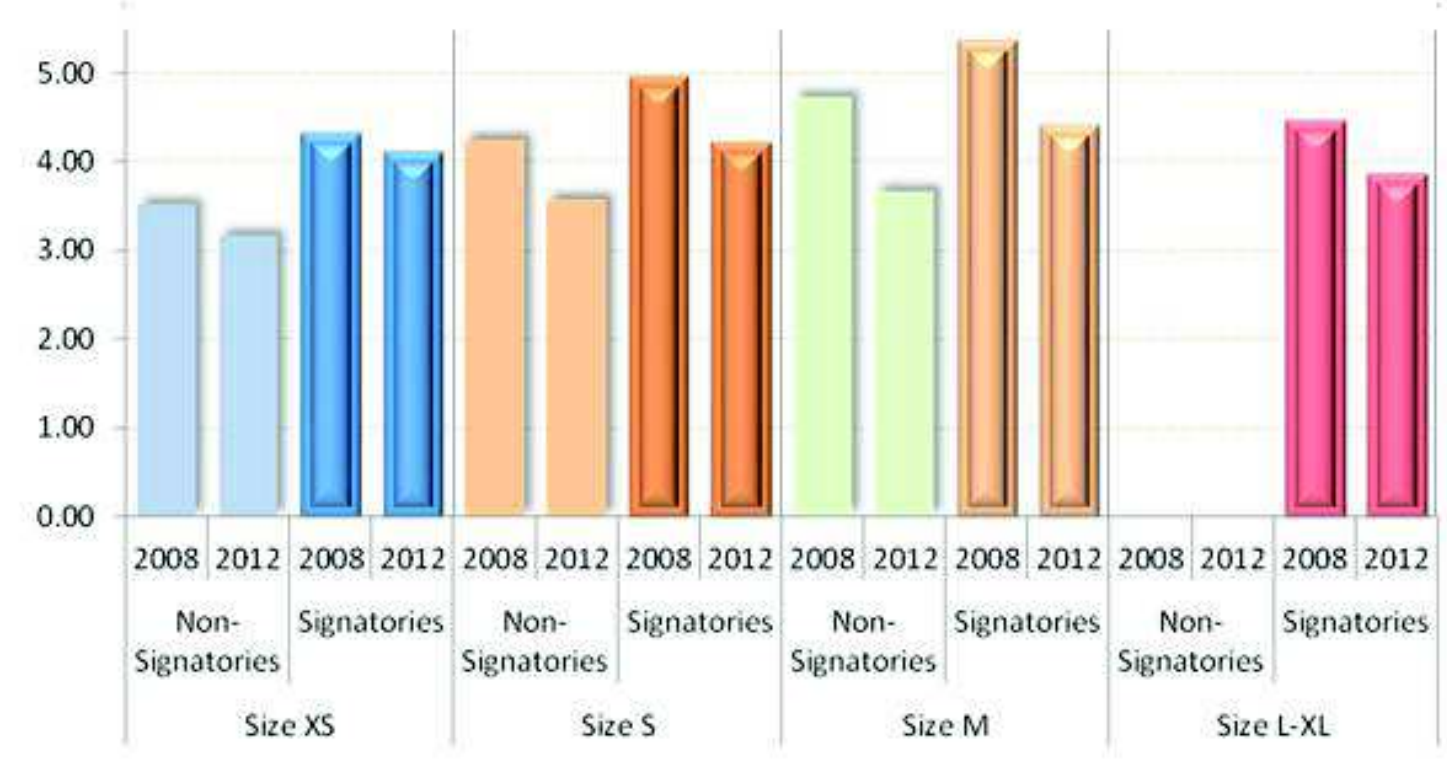

Fig. 4. Average electrical consumption per capita in the Andalusian municipalities. 2008-2012. $(\mathrm{MWh} / \mathrm{pc})$. 


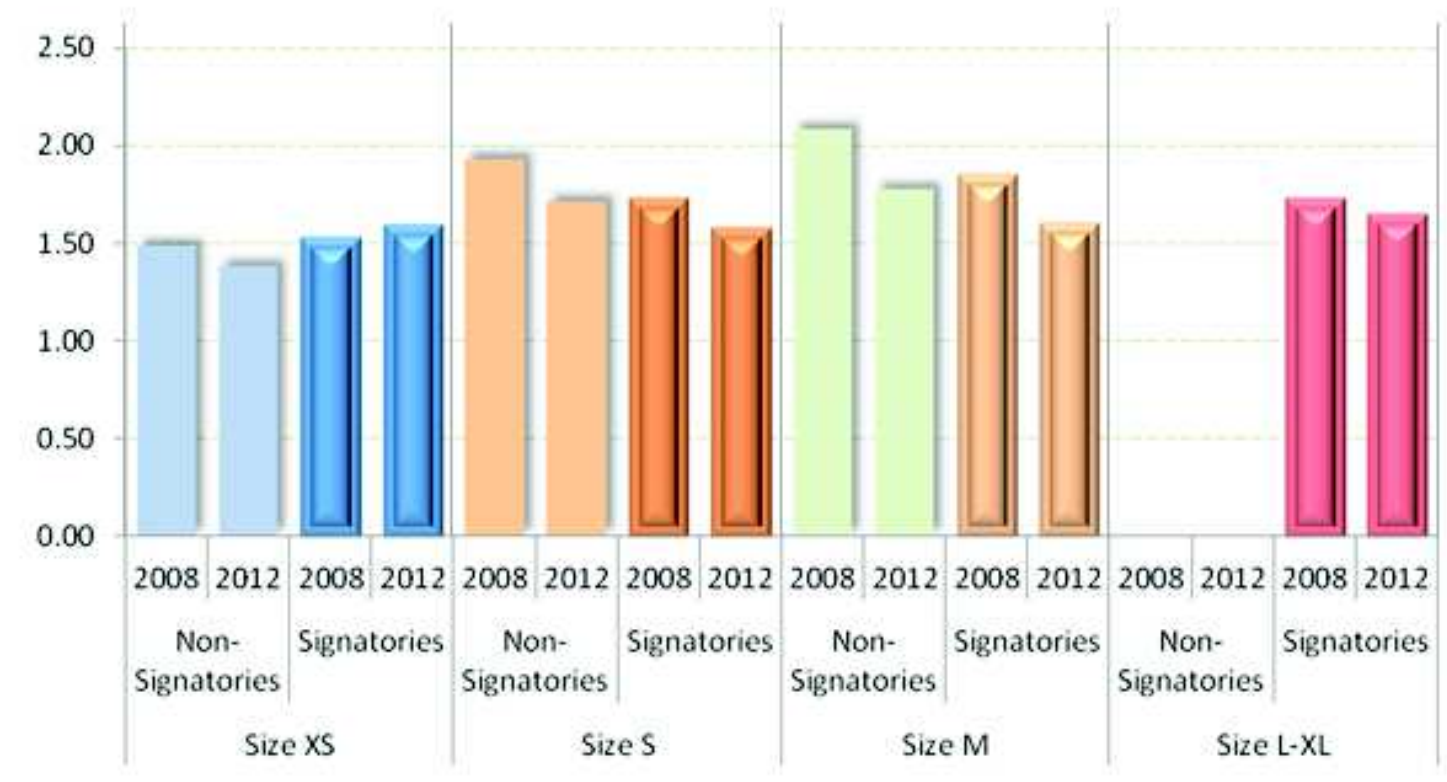

A. Residential.

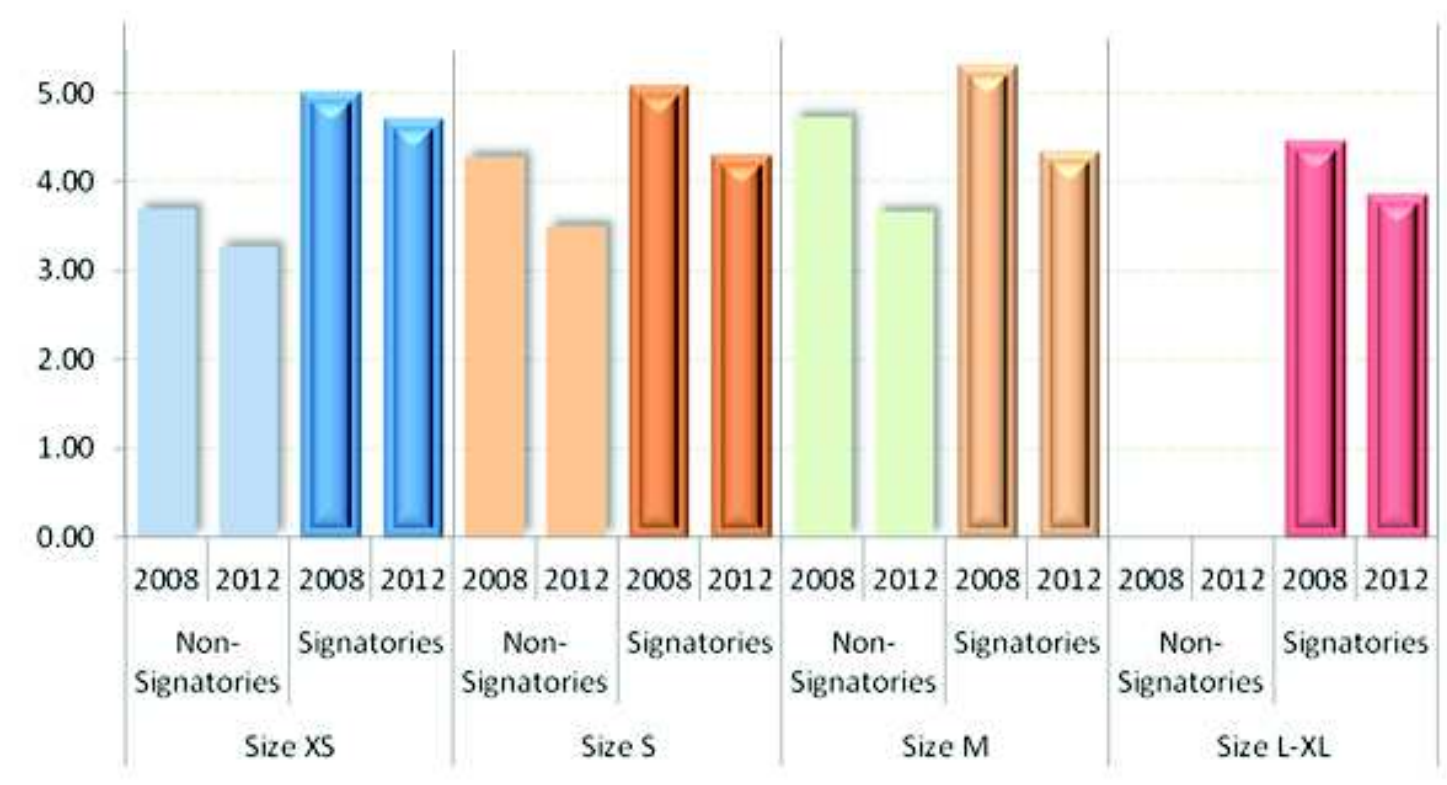

B. Public administration.

Fig. 5. Residential and public administration average electrical consumption per capita in the Andalusian municipalities. 2008-2012. (MWh/pc). 


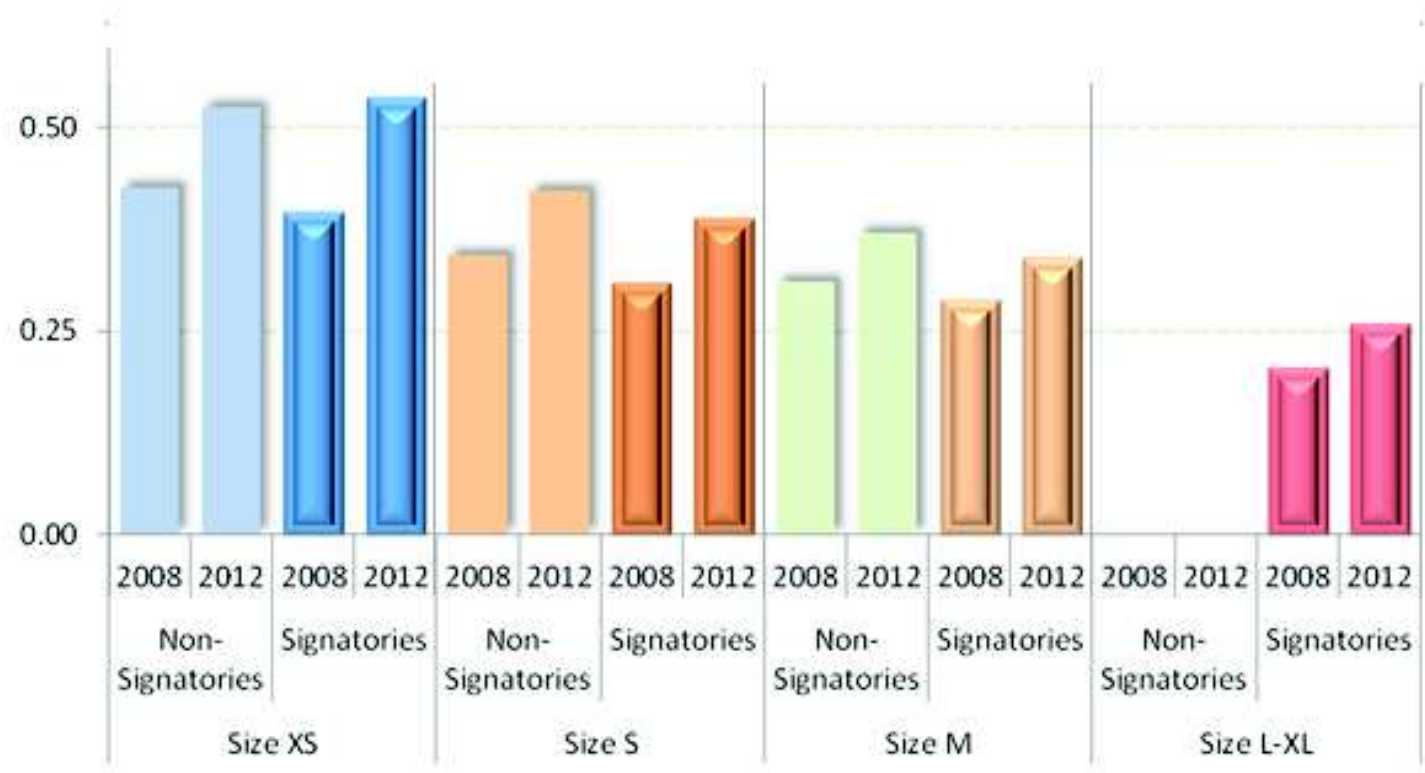

A. Residential.

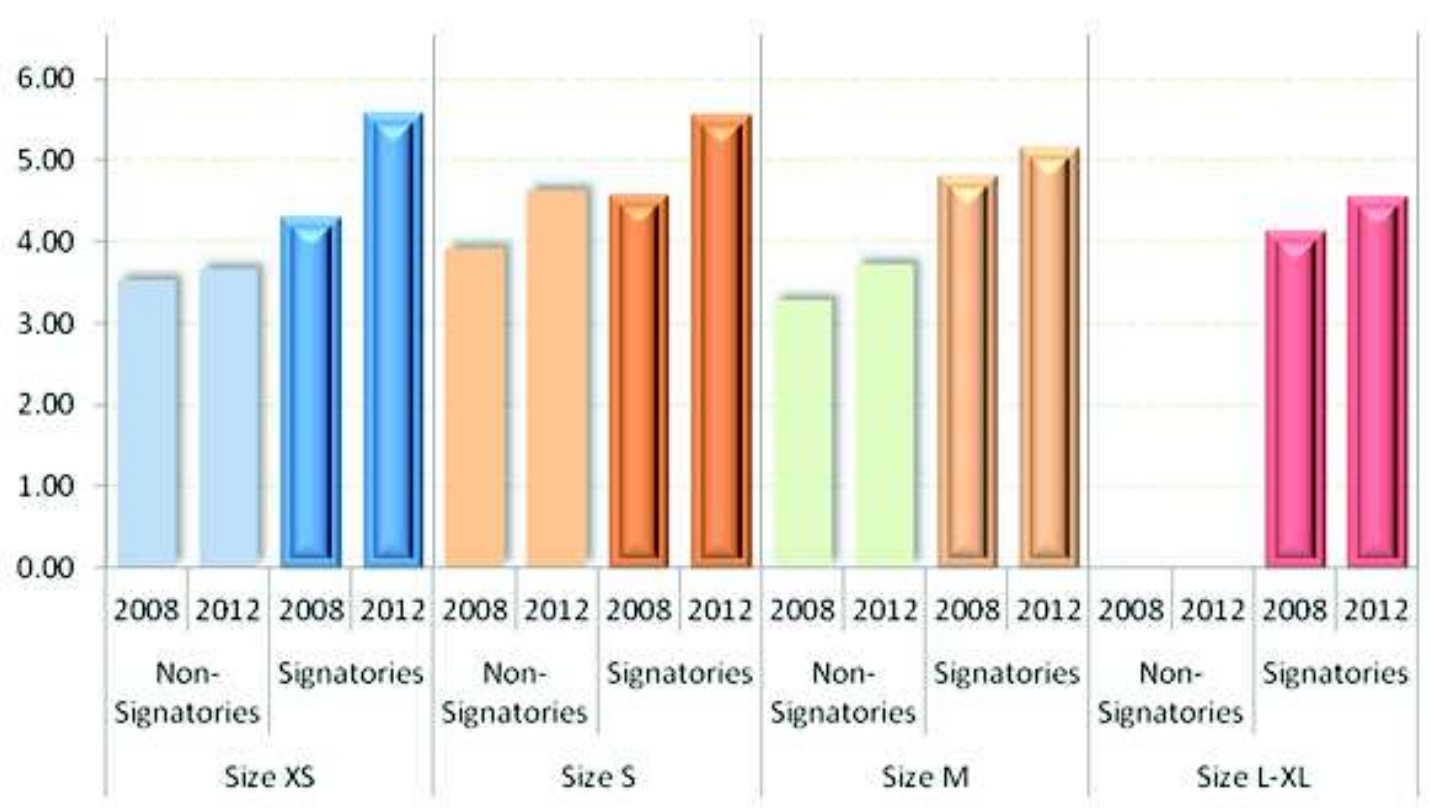

B. Public administration.

Fig. 6. Residential and public administration average electrical consumption per income in the Andalusian municipalities. 2008-2012. (MWh/1,000€) 